\title{
Synthesis and photoluminescence properties of $\mathrm{Mn}^{2+}$ doped $\mathrm{Ca}_{1-\mathrm{x}} \mathrm{Sr}_{\mathrm{x}} \mathrm{CN}_{2}$ phosphors prepared by a carbon nitride based route
}

\author{
Erwan Leysour de Rohello, Yan Suffren, Odile Merdrignac-Conanec, Olivier Guillou, Christophe \\ Calers, François Cheviré* \\ Univ Rennes 1, INSA Rennes, CNRS, ISCR (Institut des Sciences chimiques de Rennes) - UMR \\ 6226, F-35000 Rennes, France
}

${ }^{*}$ Corresponding author : $\underline{\text { francois.chevire@univ-rennes1.fr }}$

\begin{abstract}
$\mathrm{Mn}^{2+}$ doped $\mathrm{Ca}_{1-\mathrm{x}} \mathrm{Sr}_{\mathrm{x}} \mathrm{CN}_{2}$ phosphors were synthesized by a solid-state reaction in only $1 \mathrm{~h}$ under $\mathrm{NH}_{3}$ atmosphere at $700{ }^{\circ} \mathrm{C}$ from doped calcium carbonate and carbon nitride as precursors. The samples were characterized by powder X-ray diffraction, scanning electron microscopy and their diffuse reflectance and luminescence properties were investigated in order to evaluate the potential of such systems as red phosphors. All pure and well-crystallized $\mathrm{Mn}^{2+}$ doped samples exhibit broad red emission around $680 \mathrm{~nm}$ when excited at $270 \mathrm{~nm}$ at room temperature corresponding to the ${ }^{4} \mathrm{~T}_{1 \mathrm{~g}}\left({ }^{4} \mathrm{G}\right) \rightarrow{ }^{6} \mathrm{~A}_{1 \mathrm{~g}}\left({ }^{6} \mathrm{~S}\right)$ transition. Maximum emission in $\mathrm{CaCN}_{2}: \mathrm{Mn}$ is obtained for $\mathrm{Mn}^{2+}$ content of $4 \% \mathrm{~mol}$ and is stable up to $343 \mathrm{~K}$ and then shows a $20 \%$ decrease at $393 \mathrm{~K}$. Finally, the progressive substitution of $\mathrm{Sr}^{2+}$ for $\mathrm{Ca}^{2+}$ evidences a solid solution domain between $\mathrm{CaCN}_{2}$ and $\beta-\mathrm{SrCN}_{2}$ with continuous increase of the crystal lattice dimensions. However, such substitution has no impact on the wavelength emission but leads to a decrease of the luminescence efficiency of the phosphor.
\end{abstract}

Keywords: alkaline-earth, carbodiimide, carbon nitride, luminescence, phosphor

\section{Introduction}

In recent years, a great deal of interest has been focused on the synthesis and luminescence properties of a wide variety of nitrogen-based phosphors in order to obtain efficient luminescent materials for solid-state lighting applications. In particular, nitrides and oxynitrides materials present specific properties induced by nitrogen such as a greater covalent character compared to oxides. This leads to an increase of the crystal-field splitting of the $5 d$ levels resulting in a shift of the emission towards higher wavelengths when $\mathrm{Eu}^{2+}$ or $\mathrm{Ce}^{3+}$ luminescent centers are involved. Beside the rare-earth ions-doped phosphors, $\mathrm{Mn}^{2+}$-doped materials are also good candidates for solid-state lighting sources. Indeed, the wavelength position of the emission band of $\mathrm{Mn}^{2+}$ depends largely on the covalency interaction with the host crystal or the crystal field, because the $3 d$ electrons of the transition metal ions are the outermost electrons. In general, $\mathrm{Mn}^{2+}$ usually gives a green emission when it is tetrahedrally coordinated (weak crystal field), whereas octahedrally coordinated (strong crystal field) $\mathrm{Mn}^{2+}$ shows an orange to deep red emission [1].Currently, several $\mathrm{Mn}^{2+}$-doped materials are being used widely as phosphors for white-LEDs, e.g. $\mathrm{Ba}_{2} \mathrm{ZnS}_{3}$ : $\mathrm{Mn}^{2+}$ and $\mathrm{CaAlSiN}_{3}: \mathrm{Mn}^{2+}[2,3]$, fluorescent lamps, such as $\mathrm{Zn}_{2} \mathrm{SiO}_{4}: \mathrm{Mn}^{2+}$ and $\mathrm{BaAl}_{12} \mathrm{O}_{19}: \mathrm{Mn}^{2+}[4,5]$, and cathode-ray tubes, e.g. $\mathrm{ZnS}: \mathrm{Mn}^{2+}$ and $\mathrm{Zn}_{3}\left(\mathrm{PO}_{4}\right)_{2}: \mathrm{Mn}^{2+}[6-8]$. 
As part of the family of nitrogenous materials, alkaline-earth (AE) carbodiimides compounds with the general formula $\mathrm{AECN}_{2}(\mathrm{AE}=\mathrm{Mg}$, $\mathrm{Ca}, \mathrm{Sr}$ and $\mathrm{Ba}$ ) have received increasing attention due to their interesting luminescent properties [9-12]. The most famous member of the family is surely $\mathrm{CaCN}_{2}$ used as fertilizer since early $20^{\text {th }}$ century. $\mathrm{CaCN}_{2}$ crystallizes in the rhombohedral $R 3 m$ space group ( $\mathrm{n}^{\circ} 166$ ) and its crystal structure is displayed in Figure 1 . In $\mathrm{CaCN}_{2}$, the $\mathrm{Ca}^{2+}$ cation is octahedrally coordinated by nitrogen atoms within layers, that spray parallel to the (001) plane, formed by edge-sharing octahedra and connected by $[\mathrm{N}=\mathrm{C}=\mathrm{N}]^{2-}$ carbodiimide units parallel to the $c$-axis. Luminescent properties of $\mathrm{CaCN}_{2}$ doped with 5,10 and $50 \mathrm{~mol} \% \mathrm{Mn}^{2+}$ and synthesized by a solid-state metathesis reaction have been reported by Kubus et al [11]. However, they observed the formation of $\mathrm{MnCN}_{2}$ as a secondary phase which indicates that part of the manganese is not properly inserted in the $\mathrm{CaCN}_{2}$ structure. As a consequence, the effective doping rates within the matrix are significantly overestimated. As the solid-state metathesis approach requires long term annealing and controlled atmosphere, this method is not the most suitable and affordable for the preparation of large batch of phosphors. Hence, the development of a low-cost synthetic route allowing the obtention of highly crystallized doped carbodiimide materials in a reproducible and effective manner with the targeted amount of dopant within the structure is highly desirable. Recently, we reported a simple synthetic route for the preparation of highly crystallized $\mathrm{Eu}^{2+}$ doped $\mathrm{SrCN}_{2}$ materials in only one hour at $800^{\circ} \mathrm{C}$ under $\mathrm{NH}_{3}$ atmosphere using directly doped strontium carbonate and carbon nitride as precursors [13]. Therefore, the aim of the present work is to prepare a series of $\mathrm{Mn}^{2+}$ doped $\mathrm{Ca}_{1-\mathrm{x}} \mathrm{Sr}_{\mathrm{x}} \mathrm{CN}_{2}$ using the synthetic route developed in our previous study. The influence of $\mathrm{Mn}^{2+}$ doping concentration on the crystal structure and luminescent properties is investigated. Moreover, the evolution of the phosphor properties with $\mathrm{Sr}^{2+}$ substitution for $\mathrm{Ca}^{2+}$ ions will also be discussed.

\section{Experimental procedure}

\subsection{Preparation of $\mathrm{Mn}^{2+}$ doped calcium carbodiimides}

Powder samples with general formula $\mathrm{Ca}_{1-\mathrm{x}} \mathrm{Mn}_{\mathrm{x}} \mathrm{CN}_{2}(\mathrm{x}=0,0.005,0.01,0.02,0.03,0.04,0.05$ and 0.1 ) were synthesized through solid-state reaction from (doped) calcium carbonate and carbon nitride $\left(\mathrm{C}_{3} \mathrm{~N}_{4}\right)$ according to the chemical route described in Ref. [13]. $3 \mathrm{~g}$ of undoped or doped calcium carbonate precursors $\mathrm{Ca}_{1-\mathrm{x}} \mathrm{Mn}_{\mathrm{x}} \mathrm{CO}_{3}(\mathrm{x}=0,0.005,0.01,0.02,0.03,0.04,0.05$ and 0.1 ) were prepared by co-precipitation method using $\mathrm{CaCl}_{2} \cdot 6 \mathrm{H}_{2} \mathrm{O}$ (Aldrich, 98\%), $\mathrm{MnCl}_{2} \cdot 4 \mathrm{H}_{2} \mathrm{O}$ (Alfa Aesar, 99\%) and $\mathrm{Na}_{2} \mathrm{CO}_{3}$ (Acros Organics, 99.95\%) as raw materials. Appropriate amounts of calcium chloride and manganese chloride were dissolved in $100 \mathrm{~mL}$ of deionized water until obtaining a homogeneous solution, which was then added drop-wise into a $100 \mathrm{~mL}$ sodium carbonate solution under vigorous stirring (molar ratio $\mathrm{CO}_{3}{ }^{2-} / \mathrm{Ca}^{2+}=1.5$ ). A white precipitate was formed and separated from the solution by centrifugation at $4000 \mathrm{rpm}$ for $5 \mathrm{~min}$ with intermediate rinsing with deionized water $(\mathrm{x} 3)$ then ethanol $(\mathrm{x} 2)$ in order to remove any unprecipitated impurities. Finally, the resulting precipitate was dried overnight at $80^{\circ} \mathrm{C}$ in an oven to obtain the powdered (doped) calcium carbonate precursor. Carbon nitride $\left(\mathrm{C}_{3} \mathrm{~N}_{4}\right)$ powder was synthesized by heating melamine up to $550{ }^{\circ} \mathrm{C}$ for $5 \mathrm{~h}$ in a muffle furnace with a heating rate of $3{ }^{\circ} \mathrm{C} . \mathrm{min}^{-1}$. All calcium carbodiimide samples have been synthesized according to the following procedure: $500 \mathrm{mg}$ of undoped or doped calcium carbonate was thoroughly mixed with $2 \mathrm{~g}$ of carbon nitride in an agate mortar. The resulting mixture was placed in an open alumina crucible and loaded in a tubular furnace under nitrogen flow $\left(\mathrm{N}_{2}\right)$. The furnace was purged for $15 \mathrm{~min}$ before switching to ammonia $\left(\mathrm{NH}_{3}\right)$ with a flow rate of $12 \mathrm{~L} \mathrm{~h}^{-1}$. Then the mixture was heated at $700{ }^{\circ} \mathrm{C}$ for $1 \mathrm{~h}$ with a 
heating rate of $10^{\circ} \mathrm{C} \mathrm{min}^{-1}$. Thereafter, the tubular furnace was turned off and allowed to cool down to room temperature. Subsequently, the obtained powder is mixed again with $1 \mathrm{~g}$ of $\mathrm{C}_{3} \mathrm{~N}_{4}$ and annealed under the same conditions to ensure the complete reaction between the carbonate and the carbon nitride. Finally, the product was transferred and stored into a glovebox. Let us note that $\mathrm{NH}_{3}$ atmosphere was necessary to remove carbon residues during the heat treatment. The synthesis of Sr-substituted $\mathrm{Ca}_{1-\mathrm{x}} \mathrm{Mn}_{\mathrm{x}} \mathrm{CN}_{2}$ samples was carried out in a similar manner where $\mathrm{SrCl}_{2} \cdot 6 \mathrm{H}_{2} \mathrm{O}$ (Acros Organics, $\geq 99 \%$ ) is partially substituted for $\mathrm{CaCl}_{2} \cdot 6 \mathrm{H}_{2} \mathrm{O}$ at the precipitation step.

\subsection{Characterizations}

$\mathrm{X}$-ray diffraction (XRD) patterns were recorded at room temperature in the $10-90^{\circ} 2 \theta$ range with a step size of $0.0261^{\circ}$ and an effective scan time per step of $40 \mathrm{~s}$ using a PANalytical X'Pert Pro diffractometer (Cu-L2,L3 radiation, $\lambda=1.5418 \AA, 40 \mathrm{kV}, 40 \mathrm{~mA}$, PIXcel 1D detector). Data collector and HighScore Plus programs were used, respectively, for recording and analysis of the patterns. The purity of all the prepared powdered materials was systematically checked by XRD. The powder XRD patterns for Rietveld refinements were collected at room temperature in the $5-120^{\circ} 2 \theta$ range with a step size of $0.0131^{\circ}$ and an effective scan time per step of $200 \mathrm{~s}$. All calculations were carried out with Fullprof and WinPLOTR programs $[14,15]$. The pseudo-Voigt profile function was used and the background was approximated by linear interpolation between a set of background points. The lattice parameters were obtained from Rietveld refinements considering the $R 3 m$ space group $\left(\mathrm{n}^{\circ} 166\right)$. Calcium and manganese were considered occupying the same crystallographic site with respective site occupancies calculated from the targeted chemical compositions. The same thermal parameter was applied for all atoms occupying the calcium site (Wyckoff site: $3 b$ ) and the site occupancies were not refined. The estimated standard deviations (ESD) were corrected using the Berar and Lelann coefficient calculated from the structure refinement $[16,17]$.

Nitrogen and oxygen contents were determined with a LECO TC-600 Analyzer using the inert gas fusion method in which nitrogen and oxygen contents were measured as $\mathrm{N}_{2}$ by thermal conductivity and as $\mathrm{CO}_{2}$ by infrared detection respectively.

Powders morphology was examined by scanning electron microscopy (SEM) with a JEOL JSM $7100 \mathrm{~F}$ equipment (CMEBA, University of Rennes 1) operating at a $6 \mathrm{~mm}$ working distance with an accelerating voltage of $20 \mathrm{kV}$. Energy dispersive X-ray spectroscopy (EDS) characterizations were performed using a JEOL IT300 microscope operating at a $10 \mathrm{~mm}$ working distance with an accelerating voltage of $20 \mathrm{kV}$ and a probe current of $7.45 \mathrm{nA}$. Sample preparation consisted in powder deposition on a carbon tape then metallization with gold.

Thermogravimetric analysis (TGA) and differential scanning calorimetry (DSC) measurements were performed with a NETZSCH STA 449 F3 Jupiter analyzer equipped with a Proteus Analysis software. The analyses were performed in alumina crucible under simulated air $\left(\mathrm{N}_{2} / \mathrm{O}_{2}\right.$ $80 \mathrm{vol} \% / 20 \mathrm{vol} \%)$ and under nitrogen $\left(\mathrm{N}_{2}-100 \mathrm{vol} \%\right)$ in a temperature range from 20 to $985{ }^{\circ} \mathrm{C}$ with a heating rate of $10^{\circ} \mathrm{C} \mathrm{min}^{-1}$.

Diffuse reflectance spectra were collected using a Varian Cary 100 Scan spectrometer equipped with a Varian WinUV software and a Labsphere DRA-CA-30I $70 \mathrm{~mm}$ integrating sphere. Experimental data were collected within the $200-800 \mathrm{~nm}$ range with a $1 \mathrm{~nm}$ step. Band gaps of the materials $\left(E_{g}\right)$ were estimated using the Kubelka-Munk formalism [18].

Solid-state excitation and emission spectra were measured with a Horiba Jobin-Yvon Fluorolog-III fluorimeter equipped with a Xe lamp $450 \mathrm{~W}$ and a UV-Vis photomultiplier 
(Hamamatsu R928, sensitivity $190-860 \mathrm{~nm}$ ). For the measurements recorded above room temperature, the samples were placed in an adequate solid holder then introduced in the F-3004 Jobin-Yvon heating Peltier module (293 - $383 \mathrm{~K})$. Appropriate filters were utilized to remove the laser light, the Rayleigh scattered light and associated harmonics from the emission spectra. All spectra were corrected for the instrumental response function. Luminescence decays were measured directly with the fluorescence spectrometer coupled with an additional TCSPC module (Time-Correlated-Single-Photon-Counting) and a $284 \mathrm{~nm}$ pulsed Delta-Diode. Lifetimes are averages of three independent determinations.

\section{Results and discussion}

\subsection{Materials characterization}

The XRD patterns of the series of powder samples $\mathrm{Ca}_{1-\mathrm{x}} \mathrm{Mn}_{\mathrm{x}} \mathrm{CN}_{2}(\mathrm{x}=0,0.005,0.01,0.02,0.03$, $0.04,0.05$ and 0.1 ) are displayed in Figure S1. The results show that all the products can be readily indexed as rhombohedral phase and unambiguously identified as $\mathrm{CaCN}_{2}$ according to the COD card no. 153-9974 (Crystallographic Open Database, http://www.crystallography.net). However, traces of a secondary phase identified as cubic MnO (SG: Fm3m (n²25), COD card no. 151-4238) were observed in the samples with a $\mathrm{Mn}^{2+}$ doping rate greater than $4 \mathrm{~mol} \%$ as depicted on the zoomed inset on Figure S1 where the (111) and (020) lines of $\mathrm{MnO}$ are slightly noticeable at about $34.69^{\circ}$ and $40.37^{\circ}$, respectively. The powder diffraction data of the as-prepared samples were analyzed by Rietveld refinement. Details of crystal structure parameters and of the refinement as well as the atomic parameters are listed in Tables 1 and S1. Final Rietveld refinement patterns of the powders with different doping concentrations are very similar, so that only the refinement pattern of $\mathrm{Ca}_{0.96} \mathrm{Mn}_{0.04} \mathrm{CN}_{2}$ is presented in Figure 2.

The evolution of the unit cell parameters $a$ and $c$ as well as the cell volume $V$ of the samples versus the $\mathrm{Mn}^{2+}$ doping concentration are depicted in Figure 3. The linear decrease of the cell parameters $\left(a, c\right.$ and $V$ ) of the $\mathrm{Ca}_{1-\mathrm{x}} \mathrm{Mn}_{\mathrm{x}} \mathrm{CN}_{2}(0 \leq \mathrm{x} \leq 0.05)$ samples follows Vegard's law and confirms the insertion of $\mathrm{Mn}^{2+}$ within the structure of the host material $\mathrm{CaCN}_{2}$. This decrease is in agreement with the progressive substitution of $\mathrm{Mn}^{2+}\left(r_{M n^{2+}}=0.66 \AA\right)$ for $\mathrm{Ca}^{2+}\left(r_{\mathrm{Ca}^{2+}}=1.0 \AA\right)$ due to the lower ionic radius of the activator in octahedral coordination [19]. However, the experimental unit cell parameters values of $\mathrm{Ca}_{0.90} \mathrm{Mn}_{0.10} \mathrm{CN}_{2}$ sample have been found to be slightly higher than those extrapolated from the Vegard's law (i.e. $a=3.663 \AA$, $c=14.723 \AA$ and $\mathrm{V}=171.06 \AA^{3}$ ). The slight deviation from the Vegard's law suggests an incomplete insertion of $\mathrm{Mn}^{2+}$ within the structure under the used experimental conditions which is consistent with the presence of a small amount of $\mathrm{MnO}$ as a secondary phase. Moreover, the average Ca-N and C-N bond lengths for the undoped sample were determined to be $2.461 \AA$ and $1.236 \AA$, respectively, which are in good agreement with those already reported for the $\mathrm{CaCN}_{2}$ compound (i.e. $2.461 \AA$ and $1.224 \AA$, respectively) [20].

SEM images of $\mathrm{CaCN}_{2}$ and $\mathrm{Ca}_{0.96} \mathrm{Mn}_{0.04} \mathrm{CN}_{2}$ powders are presented in Figure 4. They show agglomerated powders composed of rounded shape primary particles with size in the micron range. The interconnected microstructure results from the partial sintering of the particles arising from the heat treatments at $700^{\circ} \mathrm{C}$. Note, however, that the doped powders appear slightly coarser and more sintered than the undoped powders which indicates that the dopant may act as sintering aid during the carbodiimide synthesis.

Elemental analyses were performed on each sample in order to determine the amount of dopant as well as the nitrogen and oxygen contents using EDS and the inert gas fusion technique, 
respectively. The elemental analysis data of the as-prepared powders are summarized in Table 2 . The obtained results reveal the presence of residual sodium from the carbonate precursors synthesized by co-precipitation from a sodium carbonate solution, which slightly affects the reading of the results. In order to confirm the amounts of $\mathrm{Mn}^{2+}$ introduced in the samples, the latter have been recalculated versus calcium content only (values in brackets). The obtained results confirm that the amount of $\mathrm{Mn}^{2+}$ is in good agreement with the targeted ones. A correlation between the evolution of the oxygen and the residual sodium contents can also be observed, which may suggest the presence of an oxygenated sodium-based secondary phase such as $\mathrm{NaOH}$ or $\mathrm{Na}_{2} \mathrm{CO}_{3}$ that cannot be detected by X-ray diffraction. The presence of this secondary phase may lead to an underestimation of the nitrogen content in samples with a high sodium content as observed here. We have also demonstrated that it is possible to remove sodium from the samples through increasing the synthesis temperature up to $800^{\circ} \mathrm{C}$ but at the cost of the purity of the samples. Indeed, a thermal treatment at $800^{\circ} \mathrm{C}$ leads to the formation of $\mathrm{CaO}$ and $\mathrm{MnO}$ as side-products (Figure S2).

In addition, thermal studies (TGA/DSC) were conducted in order to characterize the stability of the undoped $\mathrm{CaCN}_{2}$ sample under simulated air and nitrogen atmospheres as shown in Figure 5. Under air, the TGA signal increases from 580 to $670{ }^{\circ} \mathrm{C}$ and reveals a maximum experimental weight gain $(+5.11 \%)$ associated with an exothermic phenomenon ascribed to the partial oxidation of $\mathrm{CaCN}_{2}$ into $\mathrm{CaCO}_{3}$. Then a sudden weight loss of about $35 \%$ between 670 and $770{ }^{\circ} \mathrm{C}$ is observed which can be attributed to the rapid decomposition of the $\mathrm{CaCN}_{2}$ and $\mathrm{CaCO}_{3}$ mixture into $\mathrm{CaO}$. Under nitrogen flow, the TGA signal shows only a slight weight loss of about $1.4 \%$ between 850 and $1000^{\circ} \mathrm{C}$. Such result is in good agreement with that of Hosono et al. who did not observe any weight loss between 525 and $1000^{\circ} \mathrm{C}$ under nitrogen atmosphere [21].

\subsection{Diffuse reflection spectra}

Figure 6 shows the diffuse reflection spectra of undoped and $\mathrm{Mn}^{2+}$-doped $\mathrm{CaCN}_{2}$ samples. For undoped $\mathrm{CaCN}_{2}$ a drastic drop in reflection is observed in the ultraviolet (UV) range around $250 \mathrm{~nm}$ resulting to an estimated band gap around $5 \mathrm{eV}$ ascribed to the valence-to-conduction band transitions of $\mathrm{CaCN}_{2}$ host lattice. Due to the lack of theoretical studies on the band structure of alkaline earth carbodiimides, an approximation of band gap configuration for $\mathrm{CaCN}_{2}$ can be proposed by analogy with the band structures of the corresponding oxide and sulfide and those of transition metal carbodiimides such as $\mathrm{NiCN}_{2}$. In the case of $\mathrm{CaO}$ and $\mathrm{CaS}$, the top of the valence band has mainly a character corresponding to the $2 p(0)$ and $3 p(\mathrm{~S})$ states respectively, while the bottom of the conduction band has a character associated with the $4 s, 3 d(\mathrm{Ca})$ states for $\mathrm{CaO}$ or $3 d(\mathrm{Ca})$ states for $\mathrm{CaS}[22,23]$. In the case of $\mathrm{NiCN}_{2}$, the top of the valence band has a character attributed mainly to the $2 p(\mathrm{~N})$ states of the nitrogen atoms of the carbodiimide unit while the bottom of the conduction band is associated with the transition metal states [24]. Thus, in the case of $\mathrm{CaCN}_{2}$, it is reasonable to consider that the top of the valence band may correspond to the $2 p(\mathrm{~N})$ states and the bottom of the conduction band to the $4 s, 3 d(\mathrm{Ca})$ or $3 d(\mathrm{Ca})$ states. Moreover, the intense reflection in the visible spectral range is in agreement with the observed white daylight color of undoped $\mathrm{CaCN}_{2}$. For $\mathrm{Mn}^{2+}$-doped samples, an additional absorption band can be observed around 260-280 nm which shifts to higher wavelength with increasing the $\mathrm{Mn}^{2+}$ content. This band is ascribed to the presence of $3 d(\mathrm{Mn})$ states within the band gap of $\mathrm{CaCN}_{2}$ as the isostructural $\mathrm{MnCN}_{2}$ carbodiimide compound shows a much lower band gap [25,26]. The daylight color of doped samples shows gray-white to light-brown color depending on the $\mathrm{Mn}^{2+}$ doping rate as a 
result of the absorption in the visible range from electronic transitions between $3 d(\mathrm{Mn})$ states $[3,27]$.

\subsection{Photoluminescence properties of $\mathrm{Mn}^{2+}$ doped $\mathrm{CaCN}_{2}$ samples}

The luminescence spectra of $\mathrm{Ca}_{0.96} \mathrm{Mn}_{0.04} \mathrm{CN}_{2}$ sample at room temperature, its coordinates on the Commission Internationale de l'Éclairage (CIE) chromaticity diagram as well as a picture of the emitting phosphor under $254 \mathrm{~nm}$ UV lamp exposure are presented in Figure 7. By monitoring the emission at $680 \mathrm{~nm}$, the PLE spectrum of $\mathrm{Ca}_{0.96} \mathrm{Mn}_{0.04} \mathrm{CN}_{2}$ shows a single band originating from host lattice excitation around $250 \mathrm{~nm}$ [28]. Under excitation at $270 \mathrm{~nm}$, the emission spectrum of $\mathrm{Ca}_{0.96} \mathrm{Mn}_{0.04} \mathrm{CN}_{2}$ shows a broad emission band centered at about $680 \mathrm{~nm}$ with a full-width at half-maximum (FWHM) estimated around $115 \mathrm{~nm}$, in good agreement with reported results by Kubus et al. for $\mathrm{Ca}_{0.95} \mathrm{Mn}_{0.05} \mathrm{CN}_{2}$ phosphor [11]. The broad emission band can be ascribed to the spin-forbidden transition of the $\mathrm{Mn}^{2+}$ ion from the lowest excited level of ${ }^{4} \mathrm{~T}_{1 \mathrm{~g}}\left({ }^{4} \mathrm{G}\right)$ to the ground state ${ }^{6} \mathrm{~A}_{1 \mathrm{~g}}\left({ }^{6} \mathrm{~S}\right)$ [1], and the CIE chromaticity coordinates are $(\mathrm{x}=0.69, \mathrm{y}=0.30)$. The presence of a unique broad emission band indicates that $\mathrm{Mn}^{2+}$ occupies only one site in the lattice, namely, the octahedrally coordinated $\mathrm{Ca}^{2+}$ site of the investigated host lattice which is in line with the observed red emission. The luminescence of the $\mathrm{Mn}^{2+}$ ion is known to change depending on the host crystal field, covering a wide emission range from blue-green to red. According to the TanabeSugano diagram for a $\mathrm{d}^{5}$ configuration, increasing the crystal field reduces the energy difference between the ground $\left({ }^{6} \mathrm{~A}_{1 \mathrm{~g}}\left({ }^{6} \mathrm{~S}\right)\right)$ and first excited states $\left({ }^{4} \mathrm{~T}_{1 \mathrm{~g}}\left({ }^{4} \mathrm{G}\right)\right)$ leading to a red-shift of the luminescence [29]. An orange to red emission is basically an effect of a strong crystal field, whereas a weak crystal field usually gives a blue-green emission [1]. For comparison, a similar red emission has been observed in octahedrally coordinated $\mathrm{Mn}^{2+}$-doped phosphors such as $\mathrm{CaCO}_{3}: \mathrm{Mn}^{2+}$ with maximum of emission band at $640 \mathrm{~nm}$ [30] or CaS: $\mathrm{Mn}^{2+}$ with maximum emission band peaking around $580 \mathrm{~nm}[31,32]$. The obtained average decay time $\tau_{\mathrm{Mn} 2}+$ of $\mathrm{Ca}_{0.96} \mathrm{Mn}_{0.04} \mathrm{CN}_{2}$ was $10.7(1) \mathrm{ms}$ at $300 \mathrm{~K}$, which is typical for the parity and spin forbidden ${ }^{4} \mathrm{~T}_{1 \mathrm{~g}}\left({ }^{4} \mathrm{G}\right) \rightarrow{ }^{6} \mathrm{~A}_{1 \mathrm{~g}}\left({ }^{6} \mathrm{~S}\right)$ transition of $\mathrm{Mn}^{2+}[11,33,34]$.

Figure 8 shows the emission spectra of $\mathrm{Ca}_{1-\mathrm{x}} \mathrm{Mn}_{\mathrm{x}} \mathrm{CN}_{2}(\mathrm{x}=0.005,0.01,0.02,0.03,0.04,0.05$ and 0.1 ) samples. While the profile of emission peak does not vary with the $\mathrm{Mn}^{2+}$ content, the emission intensity of $\mathrm{Ca}_{1-\mathrm{x}} \mathrm{Mn}_{\mathrm{x}} \mathrm{CN}_{2}$ phosphors strongly depends on it. With the increase of $\mathrm{Mn}^{2+}$ doping concentration, the emission intensity increases continuously from 0.5 to $4 \mathrm{~mol} \%$ and decreases then from 4 to $10 \mathrm{~mol} \%$ (Figure 8b). Thus, the optimized $\mathrm{Mn}^{2+}$ doping concentration in the $\mathrm{CaCN}_{2}$ host lattice is about $4 \mathrm{~mol} \%$. The obtained optimal $\mathrm{Mn}^{2+}$ concentration differs from the results already published by Kubus et al. which report a value of $10 \mathrm{~mol} \%$ in the same host lattice [11]. However, they observed an additional emission band at about $560 \mathrm{~nm}$ that they ascribed to the presence of impurities. Indeed, XRD patterns of their samples clearly show the presence of MnO and $\mathrm{MnCN}_{2}$ secondary phases for the 5 and $10 \mathrm{~mol} \%$ doped samples, respectively. As a consequence, the solubility of $\mathrm{Mn}^{2+}$ ions contributing to luminescence properties in the host matrix is likely to be affected, leading to an overestimation of the optimal $\mathrm{Mn}^{2+}$ concentration in their study. Using the $\mathrm{C}_{3} \mathrm{~N}_{4}$-based synthetic route described here, no $\mathrm{MnCN}_{2}$ secondary phase was found and only traces of $\mathrm{MnO}$ impurities for Mn content $\geq 5 \mathrm{~mol} \%$ are observed as shown in the inset of Figure S1 that suggest a more effective Mn-doping process. The reduction of the emission intensity attributed to the concentration quenching effect is mainly due to the non-radiative energy transfer between neighboring $\mathrm{Mn}^{2+}$ ions in $\mathrm{CaCN}_{2}$ host. By increasing the concentration of the activators, the distances between them are reduced which results in increasing the probability of non-radiative energy transfers among the activators [35]. In addition, with increasing $\mathrm{Mn}^{2+}$ 
content, the peak positions of the emission bands show a slight red-shift from 675 to $682 \mathrm{~nm}$ (Figure 8c) which is ascribed in first approximation to the slight contraction of the lattice with the increase of $\mathrm{Mn}^{2+}$ doping rate as previously observed in the XRD study. However, in the literature, a second emission related to the formation of paired $\mathrm{Mn}^{2+}$ centers is often reported [27]. A closer look to the emission spectra shows a slight asymmetry of the emission peak. All the spectra of $\mathrm{Ca}_{1}$ ${ }_{x} \mathrm{Mn}_{\mathrm{x}} \mathrm{CN}_{2}$ samples can be well decomposed into two well-separated Gaussian components with maxima at about 13966 and $15015 \mathrm{~cm}^{-1}$ on an energy scale (corresponding to 716 and $666 \mathrm{~nm}$ ) (Figure S4) which could be ascribed to paired and single $\mathrm{Mn}^{2+}$ respectively according to literature [27].

The effect of the temperature on the emission was investigated between 296 and $393 \mathrm{~K}$ under $270 \mathrm{~nm}$ excitation wavelength. As shown in Figure 9, the emission intensity of $\mathrm{Ca}_{0.96} \mathrm{Mn}_{0.04} \mathrm{CN}_{2}$ is stable from 293 to $343 \mathrm{~K}$ and then decreases by approximately $20 \%$ up to $393 \mathrm{~K}$. Let us note that the phenomenon is completely reversible indicating that the loss of luminescence is not due to degradation of the product under the measurement conditions, which is in agreement with the thermal analyses which indicate a good stability of the product under air up to $600^{\circ} \mathrm{C}$ (i.e. $873 \mathrm{~K}$ ). The reduction of the emission intensity is induced by a higher probability of non-radiative transitions at higher temperature. Additionally, a progressive blue shift of the emission maximum with the temperature is noticeable which could result from some dilatation of the crystal lattice thus leading to a slight increase of the Ca-N bond lengths.

\subsection{Effect of partial substitution of strontium for calcium on photoluminescence properties}

As the luminescence of $\mathrm{Mn}^{2+}$ ions is strongly dependent on their crystalline environment, we can expect that substituting $\mathrm{Sr}^{2+}\left(r_{S r^{2+}}=1.18 \AA\right)$ for $\mathrm{Ca}^{2+}\left(r_{\mathrm{Ca}^{2+}}=1.0 \AA\right)$, i.e. increasing the alkaline-earth mean size, could impact the optical properties of $\mathrm{Ca}_{0.96} \mathrm{Mn}_{0.04} \mathrm{CN}_{2}$. In this context, the compounds $\mathrm{Ca}_{0.86} \mathrm{Sr}_{0.10} \mathrm{Mn}_{0.04} \mathrm{CN}_{2}, \mathrm{Ca}_{0.66} \mathrm{Sr}_{0.30} \mathrm{Mn}_{0.04} \mathrm{CN}_{2}$ and $\mathrm{Ca}_{0.46} \mathrm{Sr}_{0.50} \mathrm{Mn}_{0.04} \mathrm{CN}_{2}$ were prepared following the same synthesis protocol as that used for the unsubstituted ones in order to evaluate the impact of the increase of the unit cell volume, and thus of the ( $\mathrm{Ca} / \mathrm{Sr} / \mathrm{Mn})-\mathrm{N}$ bond lengths on the manganese emission. The XRD patterns of $\mathrm{Ca}_{0.86} \mathrm{Sr}_{0.10} \mathrm{Mn}_{0.04} \mathrm{CN}_{2}, \mathrm{Ca}_{0.66} \mathrm{Sr}_{0.30} \mathrm{Mn}_{0.04} \mathrm{CN}_{2}$ and $\mathrm{Ca}_{0.46} \mathrm{Sr}_{0.50} \mathrm{Mn}_{0.04} \mathrm{CN}_{2}$ samples are depicted in Figure 10. The results show that all the products can be readily indexed as rhombohedral phase (SG: $R 3 m$ ( $\left.\mathrm{n}^{\circ} 166\right)$, COD card no. 153-9974) and the progressive evolution of the position of the diffraction lines towards low angles as the strontium content increases indicate the formation of a solid solution over the whole investigated compositional range.

The crystal structures of the three samples were also refined using the Rietveld method. The data on which the analysis is based are derived from the refinement of the previously studied $\mathrm{Ca}_{0.96} \mathrm{Mn}_{0.04} \mathrm{CN}_{2}$ compound. Final Rietveld refinement patterns of $\mathrm{Ca}_{0.86} \mathrm{Sr}_{0.10} \mathrm{Mn}_{0.04} \mathrm{CN}_{2}$, $\mathrm{Ca}_{0.66} \mathrm{Sr}_{0.30} \mathrm{Mn}_{0.04} \mathrm{CN}_{2}$ and $\mathrm{Ca}_{0.46} \mathrm{Sr}_{0.50} \mathrm{Mn}_{0.04} \mathrm{CN}_{2}$ are presented in Figure S5, S6 and S7 while the crystal structure parameters and details of the refinement as well as the interatomic distances $\mathrm{d}_{\mathrm{Ca}(\mathrm{Sr})-\mathrm{N}}$ and $\mathrm{d}_{\mathrm{C}-\mathrm{N}}$ are presented in Table 3 (data from the $\mathrm{Ca}_{0.96} \mathrm{Mn}_{0.04} \mathrm{CN}_{2}$ sample are also included for reference). Atomic parameters are listed in Table S2. The lattice parameter as well as $\mathrm{Ca}(\mathrm{Sr})-\mathrm{N}$ bond lengths and octahedral site volumes increase with the strontium rate while concomitantly the $\mathrm{C}-\mathrm{N}$ bond length decreases within the carbodiimide unit. These results confirm the progressive substitution of $\mathrm{Sr}^{2+}\left(r_{S^{2+}}=1.18 \AA\right)$ for $\mathrm{Ca}^{2+}\left(r_{\mathrm{Ca}^{2+}}=1.0 \AA\right)$ within the structure [19].

The photoluminescence properties of the three samples were then studied to determine the impact of $\mathrm{Ca} / \mathrm{Sr}$ substitution on the emission properties of our compounds. The measurements were performed under the same conditions as those implemented for the $\mathrm{Ca}_{1-\mathrm{x}} \mathrm{Mn}_{\mathrm{x}} \mathrm{CN}_{2}$ samples 
$(0<\mathrm{x}<0.1)$. The luminescence spectra of $\mathrm{Ca}_{0.86} \mathrm{Sr}_{0.10} \mathrm{Mn}_{0.04} \mathrm{CN}_{2}, \mathrm{Ca}_{0.66} \mathrm{Sr}_{0.30} \mathrm{Mn}_{0.04} \mathrm{CN}_{2}$ and $\mathrm{Ca}_{0.46} \mathrm{Sr}_{0.50} \mathrm{Mn}_{0.04} \mathrm{CN}_{2}$ are presented in Figure 11. The emission spectra of the substituted samples show similar profiles to those of the unsubstituted sample. The intensity of the emission bands decreases with increasing strontium rates. In addition, the position of the emission bands of the substituted compounds does not vary significantly compared to the unsubstituted sample contrary to what was expected from the substitution of $\mathrm{Ca}^{2+}$ by a much larger cation such as $\mathrm{Sr}^{2+}$. Moreover, while the emission seems to be slightly red shifted for $\mathrm{Sr} / \mathrm{Ca}$ substitution up to $30 \mathrm{~mol} \%$ $\left(\lambda_{\max }=688 \mathrm{~nm}\right)$, the emission steps back a little for the $50 \mathrm{~mol} \% \mathrm{Sr}$ sample $\left(\lambda_{\max }=682 \mathrm{~nm}\right)$. Antagonistic effects should probably be considered here. While the mean ( $\mathrm{Ca}, \mathrm{Sr}, \mathrm{Mn})-\mathrm{N}$ distance increases with the $\mathrm{Sr} / \mathrm{Ca}$ substitution, the $\mathrm{C}-\mathrm{N}$ bond length within the carbodiimide units is shorten which should impact the crystal field effect of nitrogen atoms involved in the $\mathrm{MnN}_{6}$ octahedra. At the same time, the presence of a larger cation such as $\mathrm{Sr}$ in the vicinity of a much

smaller cation such as $\mathrm{Mn}\left(\mathrm{r}_{\mathrm{Mn}^{2+}}=0.66 \AA\right)$ in the $\mathrm{CaCN}_{2}$ crystal structure, may result in some local relaxation of the $\mathrm{Mn}-\mathrm{N}$ bond lengths and thus reduce the impact of the $\mathrm{Sr} / \mathrm{Ca}$ substitution. Thus, it appears that the substitution of strontium for calcium mainly has a negative impact on the emission properties of our compounds. Although it is difficult to identify the exact cause of the decrease of the emission intensity, it is probably related to the significant increase in the volume of the octahedron around $\mathrm{Mn}^{2+}$ ions from about 19.25 to $21.42 \AA^{3}$ between $\mathrm{Ca}_{0.96} \mathrm{Mn}_{0.04} \mathrm{CN}_{2}$ and $\mathrm{Ca}_{0.46} \mathrm{Sr}_{0.50} \mathrm{Mn}_{0.04} \mathrm{CN}_{2}$. The limited size of the $\mathrm{Mn}^{2+}$ ion relative to the dimensions of the octahedral site is possibly the cause of this loss of emission efficiency.

\section{Conclusion}

In this study $\mathrm{Mn}^{2+}$-doped $\mathrm{CaCN}_{2}$ phosphors have been successfully prepared using a newly developed alternative and cost-effective approach involving carbon nitride as a precursor. X-ray diffraction results attested the formation of high-purity and well-crystallized $\mathrm{Mn}^{2+}$-doped $\mathrm{CaCN}_{2}$. Structural analysis also revealed a maximum solubility of $\mathrm{Mn}^{2+}$ close to $10 \%$ within the investigated dopant concentration, with the insertion of $\mathrm{Mn}^{2+}$ within the host structure by substitution for the $\mathrm{Ca}^{2+}$ ions. $\mathrm{Mn}^{2+}$-doped $\mathrm{CaCN}_{2}$ phosphors exhibit a broad band emission with a peak centered at $680 \mathrm{~nm}$ at room temperature under $270 \mathrm{~nm}$ excitation wavelength. The optimized $\mathrm{Mn}^{2+}$ concentration of $\mathrm{CaCN}_{2}: \mathrm{Mn}^{2+}$ is 4 at $\%$. With temperature increasing, the emission intensity of $\mathrm{Ca}_{0.96} \mathrm{Mn}_{0.04} \mathrm{CN}_{2}$ sample is stable from 293 to $343 \mathrm{~K}$ and then decreases by approximately $20 \%$ up to $393 \mathrm{~K}$. In addition, we have shown that the substitution of calcium by strontium, while evidencing a solid solution domain between $\mathrm{CaCN}_{2}$ and $\beta-\mathrm{SrCN}_{2}$, has a negative impact on the emission properties of our compounds. Nevertheless, according to the interesting luminescent properties, $\mathrm{Mn}^{2+}$ doped $\mathrm{CaCN}_{2}$ phosphors may be of interest for applications in the field of fluorescent light sources.

\section{Acknowledgements}

SEM experiments were performed on CMEBA platform (ScanMAT, UMS 2011 University of Rennes 1-

CNRS; CPER-FEDER 2007-2014).

\section{References}

[1] G. Blasse, B.C. Grabmaier, Luminescent Materials, Springer-Verlag, 1994. https://doi.org/10.1007/978-3-642-79017-1_1. 
[2] X. Zhang, H. Zeng, Q. Su, $\mathrm{Mn}^{2+}$-doped $\mathrm{Ba}_{2} \mathrm{ZnS}_{3}$ phosphor as a potential luminescent material for white LEDs, J. Alloys Compd. 441 (2007) 259-262.

https://doi.org/10.1016/j.jallcom.2006.09.090.

[3] Z. Zhang, A.C.A. Delsing, P.H.L. Notten, J. Zhao, P. Dorenbos, H.T. Hintzen, Photoluminescence Properties of Red-Emitting $\mathrm{Mn}^{2+}$-Activated CaAlSiN 3 Phosphor for White-LEDs, ECS J. Solid State Sci. Technol. 2 (2013) R70-R75. https://doi.org/10.1149/2.017304jss.

[4] R.P. Sreekanth Chakradhar, B.M. Nagabhushana, G.T. Chandrappa, K.P. Ramesh, J.L. Rao, Solution combustion derived nanocrystalline $\mathrm{Zn}_{2} \mathrm{SiO}_{4}$ :Mn phosphors: A spectroscopic view, J. Chem. Phys. 121 (2004) 10250-10259. https://doi.org/10.1063/1.1808420.

[5] D.Y. Lee, Y.C. Kang, H.D. Park, S.K. Ryu, VUV characteristics of BaAl12019:Mn2+ phosphor particles prepared from aluminum polycation solutions by spray pyrolysis, J. Alloys Compd. 353 (2003) 252-256. https://doi.org/10.1016/S0925-8388(02)01197-0.

[6] Y. Hattori, T. Isobe, H. Takahashi, S. Itoh, Luminescent properties of $\mathrm{ZnS:Mn}{ }^{2+}$ nanocrystals/SiO2 hybrid phosphor synthesized by in situ surface modification coprecipitation, J. Lumin. 113 (2005) 69-78. https://doi.org/10.1016/j.jlumin.2004.08.054.

[7] A.L. Smith, Luminescence of Three Forms of Zinc Orthophosphate:Mn, J. Electrochem. Soc. 98 (1951) 363. https://doi.org/10.1149/1.2778220.

[8] J.K. Berkowitz, J.A. Olsen, Investigation of luminescent materials under ultraviolet excitation energies from 5 to $25 \mathrm{eV}$, J. Lumin. 50 (1991) 111-121. https://doi.org/10.1016/0022-2313(91)90025-Q.

[9] S. Yuan, Y. Yang, F. Chevire, F. Tessier, X. Zhang, G. Chen, Photoluminescence of Eu ${ }^{2+-D o p e d}$ Strontium Cyanamide: A Novel Host Lattice for $\mathrm{Eu}^{2+}$, J. Am. Ceram. Soc. 93 (2010) 30523055. https://doi.org/10.1111/j.1551-2916.2010.04025.x.

[10] M. Krings, G. Montana, R. Dronskowski, C. Wickleder, $\alpha$-SrNCN:Eu ${ }^{2+}-$ A Novel Efficient Orange-Emitting Phosphor, Chem. Mater. 23 (2011) 1694-1699. https://doi.org/10.1021/cm102262u.

[11] M. Kubus, C. Castro, D. Enseling, T. Jüstel, Room temperature red emitting carbodiimide compound $\mathrm{Ca}\left(\mathrm{CN}_{2}\right): \mathrm{Mn}^{2+}$, Opt. Mater. 59 (2016) 126-129. https://doi.org/10.1016/j.optmat.2016.01.006.

[12] Y. Masubuchi, S. Nishitani, A. Hosono, Y. Kitagawa, J. Ueda, S. Tanabe, H. Yamane, M. Higuchi, S. Kikkawa, Red-emission over a wide range of wavelengths at various temperatures from tetragonal $\mathrm{BaCN}_{2}: \mathrm{Eu}^{2+}$, J. Mater. Chem. C. 6 (2018) 6370-6377. https://doi.org/10.1039/C8TC01289J.

[13] E. Leysour de Rohello, Y. Suffren, O. Merdrignac-Conanec, O. Guillou, F. Cheviré, Effect of cationic substitutions on the photoluminescence properties of $\mathrm{Eu}^{2+}$ doped $\mathrm{SrCN}_{2}$ prepared by a facile C3N4 based synthetic approach, J. Eur. Ceram. Soc. 40 (2020) 6316-6321. https://doi.org/10.1016/j.jeurceramsoc.2019.12.002.

[14] J. Rodríguez-Carvajal, Recent advances in magnetic structure determination by neutron powder diffraction, Phys. B Condens. Matter. 192 (1993) 55-69. https://doi.org/10.1016/0921-4526(93)90108-I.

[15] T. Roisnel, J. Rodríguez-Carvajal, WinPLOTR: A Windows tool for powder diffraction pattern analysis, Mater. Sci. Forum: Eur. Powder Diffraction EPDIC7 378-381, (2001) 118123. https://doi.org/10.4028/www.scientific.net/MSF.378-381.118.

[16] J.-F. Bérar, Data optimization and propagation of errors in powder diffraction, "Acc. Pow. Diff II", NIST sp. Pub 846 (1992), p. 63.

[17] J.-F. Bérar, P. Lelann, E.s.d.'s and estimated probable error obtained in Rietveld refinements with local correlations, J. Appl. Crystallogr. 24 (1991) 1-5. https://doi.org/10.1107/S0021889890008391.

[18] D. Kubelka, L. Munk, Ein Beitrag zur Optik der Farbanstriche, Z. Tech. Phys. 12, (1931) 593601. 
[19] R.D. Shannon, Revised effective ionic radii and systematic studies of interatomic distances in halides and chalcogenides, Acta Crystallogr. A. 32 (1976) 751-767. https://doi.org/10.1107/S0567739476001551.

[20] N.G. Vannerberg, The crystal structure of calcium carbodiimide, 16 (1962) 2263-2266.

[21] A. Hosono, R.P. Stoffel, Y. Masubuchi, R. Dronskowski, S. Kikkawa, Melting Behavior of Alkaline-Earth Metal Carbodiimides and Their Thermochemistry from First-Principles, Inorg. Chem. 58 (2019) 8938-8942. https://doi.org/10.1021/acs.inorgchem.9b01462.

[22] M. Springborg, O.E. Taurian, Self-consistent electronic structures of $\mathrm{CaO}$ and $\mathrm{BaO}$, J. Phys. C Solid State Phys. 19 (1986) 6347-6355. https://doi.org/10.1088/0022-3719/19/32/010.

[23] C.W. Raubach, A.F. Gouveia, Y.V.B. de Santana, J.A. Varela, M.M. Ferrer, M.S. Li, E. Longo, Towards controlled synthesis and better understanding of blue shift of the CaS crystals, J. Mater. Chem. C. 2 (2014) 2743-2750. https://doi.org/10.1039/C3TC32115K.

[24] T. Jiang, B. Polteau, Y. Farré, L. Cario, C. Latouche, Y. Pellegrin, M. Boujtita, F. Odobel, F. Tessier, F. Cheviré, S. Jobic, Experimental and Theoretical Evidences of p-Type Conductivity in Nickel Carbodiimide Nanoparticles with a Delafossite Structure Type, Inorg. Chem. 56 (2017) 7922-7927. https://doi.org/10.1021/acs.inorgchem.7b00636.

[25] T.D. Boyko, R.J. Green, R. Dronskowski, A. Moewes, Electronic Band Gap Reduction in Manganese Carbodiimide: MnNCN, J. Phys. Chem. C. 117 (2013) 12754-12761. https://doi.org/10.1021/jp4000768.

[26] X. Liu, M. Krott, P. Müller, C. Hu, H. Lueken, R. Dronskowski, Synthesis, Crystal Structure, and Properties of MnNCN, the First Carbodiimide of a Magnetic Transition Metal, Inorg. Chem. 44 (2005) 3001-3003. https://doi.org/10.1021/ic050050a.

[27] C.J. Duan, A.C.A. Delsing, H.T. Hintzen, Red emission from $\mathrm{Mn}^{2+}$ on a tetrahedral site in $\mathrm{MgSiN}_{2}$, J. Lumin. 129 (2009) 645-649. https://doi.org/10.1016/j.jlumin.2009.01.010.

[28] X. Tong, J. Yang, P. Wu, X. Zhang, H.J. Seo, Color tunable emission from $\mathrm{CaS}: \mathrm{Cu}^{+}, \mathrm{Mn}^{2+}$ rareearth-free phosphors prepared by a simple carbon-thermal reduction method, J. Alloys Compd. 779 (2019) 399-403. https://doi.org/10.1016/j.jallcom.2018.11.325.

[29] Q. Zhou, L. Dolgov, A.M. Srivastava, L. Zhou, Z. Wang, J. Shi, M.D. Dramićanin, M.G. Brik, M. $\mathrm{Wu}, \mathrm{Mn}^{2+}$ and $\mathrm{Mn}^{4+}$ red phosphors: synthesis, luminescence and applications in WLEDs. A review, J. Mater. Chem. C. 6 (2018) 2652-2671. https://doi.org/10.1039/C8TC00251G.

[30] J. Nara, S. Adachi, Photoluminescence properties of $\left(\mathrm{Ce}^{3+}, \mathrm{Mn}^{2+}\right)$-codoped $\mathrm{CaCO}_{3}$ red phosphor, J. Appl. Phys. 113 (2013) 033519. https://doi.org/10.1063/1.4779856.

[31] N. Yamashita, S. Maekawa, K. Nakamura, Influence of Paired $\mathrm{Mn}^{2+}$ Centers on the Luminescence Spectra of CaS:Mn²+, Jpn. J. Appl. Phys. 29 (1990) 1729. https://doi.org/10.1143/JJAP.29.1729.

[32] T. Yamase, Emission center of CaS: $\operatorname{Mn}_{(\mathrm{x})}(\mathrm{x}=0.1,0.3,0.8,1.3$ at.\%) powders, Inorganica Chim. Acta. 114 (1986) L35-L37. https://doi.org/10.1016/S0020-1693(00)86437-3.

[33] L. Shi, Y. Huang, H.J. Seo, Emission Red Shift and Unusual Band Narrowing of $\mathrm{Mn}^{2+}$ in $\mathrm{NaCaPO}_{4}$ Phosphor, J. Phys. Chem. A. 114 (2010) 6927-6934. https://doi.org/10.1021/jp101772z.

[34] C. Barthou, J. Benoit, P. Benalloul, A. Morell, $\mathrm{Mn}^{2+}$ Concentration Effect on the Optical Properties of $\mathrm{Zn}_{2} \mathrm{SiO}_{4}$ : Mn Phosphors, J. Electrochem. Soc. 141 (1994) 524-528. https://doi.org/10.1149/1.2054759.

[35] D.L. Dexter, J.H. Schulman, Theory of Concentration Quenching in Inorganic Phosphors, J. Chem. Phys. 22 (1954) 1063. https://doi.org/10.1063/1.1740265. 


\section{Figure and table captions}

Figure 1. Crystal structure of $\mathrm{CaCN}_{2}$ with $\mathrm{CaN}_{6}$ octahedra drawn in light green, $\mathrm{Ca}$ atoms in green, $\mathrm{C}$ atoms in grey and $\mathrm{N}$ atoms in blue.

Figure 2. Final Rietveld refinement pattern for $\mathrm{Ca}_{0.96} \mathrm{Mn}_{0.04} \mathrm{CN}_{2}$ : observed (red dotted line), calculated (black full line) and difference (blue line) X-ray powder diffraction profiles from the pattern matching plot obtained with Fullprof. The vertical markers correspond to the position of the Bragg reflections.

Figure 3. Evolution of the unit cell parameters $a, c$ and cell volume $V$ in $\mathrm{Ca}_{1-\mathrm{x}} \mathrm{Mn}_{\mathrm{x}} \mathrm{CN}_{2}(0<\mathrm{x}<0.1)$ samples versus $\mathrm{Mn}^{2+}$ doping concentration.

Figure 4. SEM images of (a-c) $\mathrm{CaCN}_{2}$ and (d-f) $\mathrm{Ca}_{0.96} \mathrm{Mn}_{0.04} \mathrm{CN}_{2}$ powders.

Figure 5. TGA and DSC curves of $\mathrm{CaCN}_{2}$ under air (full curves) and nitrogen (dashed curves).

Figure 6. Solid-state diffuse reflection spectra of undoped and $\mathrm{Mn}^{2+}$-doped $\mathrm{CaCN}_{2}$ samples at room temperature. In inset: Appearance of $\mathrm{CaCN}_{2}$ and $\mathrm{Ca}_{0.96} \mathrm{Mn}_{0.04} \mathrm{CN}_{2}$ powders in daylight.

Figure 7. Solid-state excitation and emission spectra at room temperature of $\mathrm{Ca}_{0.96} \mathrm{Mn}_{0.04} \mathrm{CN}_{2}$. In inset: The CIE chromaticity diagram, chromaticity coordinates, and picture under $254 \mathrm{~nm}$ UV lamp.

Figure 8. (a) Solid-state emission spectra at room temperature of $\mathrm{Ca}_{1-\mathrm{x}} \mathrm{Mn}_{\mathrm{x}} \mathrm{CN}_{2}(0<\mathrm{x}<0.1)$

samples. (b) Normalized emission intensity ( $\left.\mathrm{E}_{\max }\right)$ vs $x(0 \leq x \leq 0.1)$ for $\mathrm{Ca}_{1-\mathrm{x}} \mathrm{Mn}_{\mathrm{x}} \mathrm{CN}_{2}$. Uncertainty bars $= \pm 0.05$.

(c) Dependance of emission wavelength on $\mathrm{Mn}^{2+}$ concentration.

Figure 9. (a) Solid-state emission $\left(\lambda_{\mathrm{ex}}=270 \mathrm{~nm}\right)$ spectra of $\mathrm{Ca}_{0.96} \mathrm{Mn}_{0.04} \mathrm{CN}_{2}$ at variable temperature (296-393 K). (b) Normalized emission intensity ( $\left.E_{\max }\right) v s$ temperature $(296-393 \mathrm{~K})$ for $\mathrm{Ca}_{0.96} \mathrm{Mn}_{0.04} \mathrm{CN}_{2}$. Uncertainty bars $= \pm 0.05$.

Figure 10. (a) Powder X-ray diffraction diagrams of $\mathrm{Ca}_{0.86} \mathrm{Sr}_{0.10} \mathrm{Mn}_{0.04} \mathrm{CN}_{2}, \mathrm{Ca}_{0.66} \mathrm{Sr}_{0.30} \mathrm{Mn}_{0.04} \mathrm{CN}_{2}$ and $\mathrm{Ca}_{0.46} \mathrm{Sr}_{0.50} \mathrm{Mn}_{0.04} \mathrm{CN}_{2}$ samples. (b) Evolution of the unit cell parameters $a, c$ and cell volume $V$ in $\mathrm{Ca}_{0.96-\mathrm{x}} \mathrm{Sr}_{\mathrm{x}} \mathrm{Mn}_{0.04} \mathrm{CN}_{2}(0<\mathrm{x}<0.5)$ samples as a function of $\mathrm{Sr}^{2+}$ doping concentration.

Figure 11. Solid-state emission spectra at room temperature of $\mathrm{Ca}_{0.86} \mathrm{Sr}_{0.10} \mathrm{Mn}_{0.04} \mathrm{CN}_{2}$, $\mathrm{Ca}_{0.66} \mathrm{Sr}_{0.30} \mathrm{Mn}_{0.04} \mathrm{CN}_{2}$ and $\mathrm{Ca}_{0.46} \mathrm{Sr}_{0.50} \mathrm{Mn}_{0.04} \mathrm{CN}_{2}$ samples. (b) Normalized emission intensity ( $\left.\mathrm{E}_{\max }\right) v s$ $x(0 \leq x \leq 0.5)$ for $\mathrm{Ca}_{0.96-x} \mathrm{Sr}_{x} \mathrm{Mn}_{0.04} \mathrm{CN}_{2}$. Uncertainty bars $= \pm 0.05$.

Table 1. Details of the Rietveld refinement of the $\mathrm{Ca}_{1-\mathrm{x}} \mathrm{Mn}_{\mathrm{x}} \mathrm{CN}_{2}$ samples diagrams.

Table 2. Chemical composition and $\mathrm{Mn}^{2+}$ content of $\mathrm{Ca}_{1-\mathrm{x}} \mathrm{Mn}_{\mathrm{x}} \mathrm{CN}_{2}(0<\mathrm{x}<0.1)$ samples.

Table 3. Details of the Rietveld refinements of $\mathrm{Ca}_{0.86} \mathrm{Sr}_{0.10} \mathrm{Mn}_{0.04} \mathrm{CN}_{2}, \mathrm{Ca}_{0.66} \mathrm{Sr}_{0.30} \mathrm{Mn}_{0.04} \mathrm{CN}_{2}$ and $\mathrm{Ca}_{0.46} \mathrm{Sr}_{0.50} \mathrm{Mn}_{0.04} \mathrm{CN}_{2}$. 
Table 1. Details of the Rietveld refinement of the $\mathrm{Ca}_{1-\mathrm{x}} \mathrm{Mn}_{\mathrm{x}} \mathrm{CN}_{2}$ samples diagrams.

\begin{tabular}{|c|c|c|c|c|c|c|c|c|}
\hline $\mathrm{Mn}^{2+}(\%)$ & 0 & 0.5 & 1 & 2 & 3 & 4 & 5 & 10 \\
\hline \multicolumn{4}{|c|}{ Space group, Z } & \multicolumn{5}{|c|}{ Rhombohedral, $R \overline{3} m$ (n¹66), 3} \\
\hline \multicolumn{9}{|c|}{ Lattice parameters } \\
\hline$a(\AA)$ & $3.6970(1)$ & $3.6953(2)$ & $3.6938(2)$ & $3.6900(1)$ & $3.6872(1)$ & $3.6834(1)$ & $3.6802(1)$ & $3.6672(1)$ \\
\hline$c(\AA)$ & $14.767(1)$ & $14.764(1)$ & $14.762(1)$ & $14.7589(6)$ & $14.7532(8)$ & $14.7491(3)$ & $14.7444(6)$ & $14.724(1)$ \\
\hline Volume $\left(\AA^{3}\right)$ & $174.81(2)$ & $174.61(2)$ & $174.44(2)$ & $174.03(1)$ & $173.71(1)$ & $173.30(1)$ & $172.94(1)$ & $171.50(2)$ \\
\hline \multicolumn{9}{|c|}{ Figure of merits } \\
\hline$R_{p}(\%)$ & 16.3 & 16.4 & 16.0 & 15.0 & 15.3 & 14.7 & 15.4 & 20.5 \\
\hline$R_{w p}(\%)$ & 16.6 & 16.5 & 15.8 & 14.6 & 14.5 & 13.7 & 14.2 & 17.0 \\
\hline$R_{\exp }(\%)$ & 9.05 & 9.09 & 9.15 & 8.86 & 9.08 & 9.20 & 9.23 & 10.1 \\
\hline $\boldsymbol{R}_{\text {bragg }}$ & 3.20 & 3.55 & 3.39 & 3.43 & 3.28 & 2.80 & 3.16 & 4.40 \\
\hline$x^{2}$ & 3.37 & 3.29 & 2.97 & 2.72 & 2.55 & 2.22 & 2.37 & 2.83 \\
\hline \multicolumn{9}{|c|}{ Interatomic distances for the $\mathrm{CaN}_{6}$ octahedron and the [NCN] carbodiimide unit } \\
\hline$d_{(C a-N)}(\AA)$ & 2.4604 & 2.4594 & 2.4608 & 2.4587 & 2.4571 & 2.4572 & 2.4517 & 2.4496 \\
\hline$d_{(C-N)}(\AA)$ & 1.2375 & 1.2372 & 1.2326 & 1.2324 & 1.2319 & 1.2271 & 1.2341 & 1.2221 \\
\hline
\end{tabular}


Table 2. Chemical composition and $\mathrm{Mn}^{2+}$ content of $\mathrm{Ca}_{1-x} \mathrm{Mn}_{x} \mathrm{CN}_{2}(0<x<0.1)$ samples.

\begin{tabular}{|c|c|c|c|c|c|c|c|}
\hline & Ca at\% & Mn at\%* & $\mathrm{Na}$ at\% & $N_{\text {exp }} w t \%$ & $\mathbf{N}_{\text {calc }} \mathbf{w t} \%$ & $\Delta \mathbf{N} \% * *$ & O wt\% \\
\hline $\mathrm{CaCN}_{2}$ & 99.53 & - & 0.47 & 35.19 & 34.96 & 0.66 & 0.29 \\
\hline $\mathrm{Ca}_{0.995} \mathrm{Mn}_{0.005} \mathrm{CN}_{2}$ & 98.27 & $0.56(0.56)$ & 1.17 & 35.32 & 34.93 & 1.12 & 0.39 \\
\hline $\mathrm{Ca}_{0.99} \mathrm{Mn}_{0.01} \mathrm{CN}_{2}$ & 97.00 & 1.15 (1.17) & 1.85 & 35.94 & 34.90 & 2.98 & 0.43 \\
\hline $\mathrm{Ca}_{0.98} \mathrm{Mn}_{0.02} \mathrm{CN}_{2}$ & 95.30 & $2.10(2.16)$ & 2.59 & 35.34 & 34.83 & 1.46 & 0.72 \\
\hline $\mathrm{Ca}_{0.97} \mathrm{Mn}_{0.03} \mathrm{CN}_{2}$ & 95.91 & $3.24(3.26)$ & 0.83 & 34.21 & 34.77 & 1.61 & 0.35 \\
\hline $\mathrm{Ca}_{0.96} \mathrm{Mn}_{0.04} \mathrm{CN}_{2}$ & 92.25 & $4.42(4.57)$ & 3.32 & 34.55 & 34.70 & 0.43 & 0.69 \\
\hline $\mathrm{Ca}_{0.95} \mathrm{Mn}_{0.05} \mathrm{CN}_{2}$ & 90.82 & $4.86(5.07)$ & 4.32 & 33.35 & 34.64 & 3.72 & 0.89 \\
\hline $\mathrm{Ca}_{0.90} \mathrm{Mn}_{0.10} \mathrm{CN}_{2}$ & 85.76 & $10.19(10.62)$ & 4.04 & 33.35 & 34.33 & 2.85 & 0.88 \\
\hline
\end{tabular}

*Values without brackets represent $\mathrm{Mn}$ rates taking into account $\mathrm{Na}$; The values in brackets are the Mn rates recalculated without considering $\mathrm{Na}$.

**Deviation of the experimental nitrogen rate from the theoretical value. 
Table 3. Details of the Rietveld refinements of $\mathrm{Ca}_{0.86} \mathrm{Sr}_{0.10} \mathrm{Mn}_{0.04} \mathrm{CN}_{2}, \mathrm{Ca}_{0.66} \mathrm{Sr}_{0.30} \mathrm{Mn}_{0.04} \mathrm{CN}_{2}$ and $\mathrm{Ca}_{0.46} \mathrm{Sr}_{0.50} \mathrm{Mn}_{0.04} \mathrm{CN}_{2}$.

\begin{tabular}{|c|c|c|c|c|}
\hline Compounds & $\mathrm{Ca}_{0.96} \mathrm{Mn}_{0.04} \mathrm{CN}_{2}$ & $\mathrm{Ca}_{0.86} \mathrm{Sr}_{0.10} \mathrm{Mn}_{0.04} \mathrm{CN}_{2}$ & $\mathrm{Ca}_{0.66} \mathrm{Sr}_{0.30} \mathrm{Mn}_{0.04} \mathrm{CN}_{2}$ & $\mathrm{Ca}_{0.46} \mathrm{Sr}_{0.50} \mathrm{Mn}_{0.04} \mathrm{CN}_{2}$ \\
\hline \multicolumn{5}{|c|}{ Lattice parameters } \\
\hline$a(\AA)$ & $3.6834(1)$ & $3.7154(1)$ & $3.7697(1)$ & $3.8347(1)$ \\
\hline$c(\AA ̊)$ & $14.7491(3)$ & $14.772(7)$ & $14.817(1)$ & $14.876(1)$ \\
\hline$V\left(\AA^{3}\right)$ & $173.30(1)$ & $176.60(1)$ & $182.36(8)$ & $189.46(2)$ \\
\hline \multicolumn{5}{|c|}{ Figure of merits } \\
\hline$R_{p}(\%)$ & 14.7 & 17.6 & 19.4 & 16.6 \\
\hline$R_{w p}(\%)$ & 13.7 & 13.8 & 13.0 & 11.5 \\
\hline$R_{\exp }(\%)$ & 9.20 & 9.43 & 8.97 & 8.15 \\
\hline$R_{\text {Bragg }}$ & 2.80 & 2.62 & 4.02 & 2.92 \\
\hline$\chi^{2}$ & 2.22 & 2.13 & 2.11 & 1.98 \\
\hline \multicolumn{5}{|c|}{ Interatomic distances } \\
\hline$d_{C a(S r)-N}(\AA)$ & 2.4575 & 2.4756 & 2.5100 & 2.5479 \\
\hline$d_{C-N}(\AA ̊)$ & 1.2267 & 1.2262 & 1.2193 & 1.2183 \\
\hline \multicolumn{5}{|c|}{ Octahedral site volumes } \\
\hline$V_{\text {Octahedra }}\left(\AA^{3}\right)$ & 19.2553 & 19.6977 & 20.5145 & 21.4176 \\
\hline
\end{tabular}




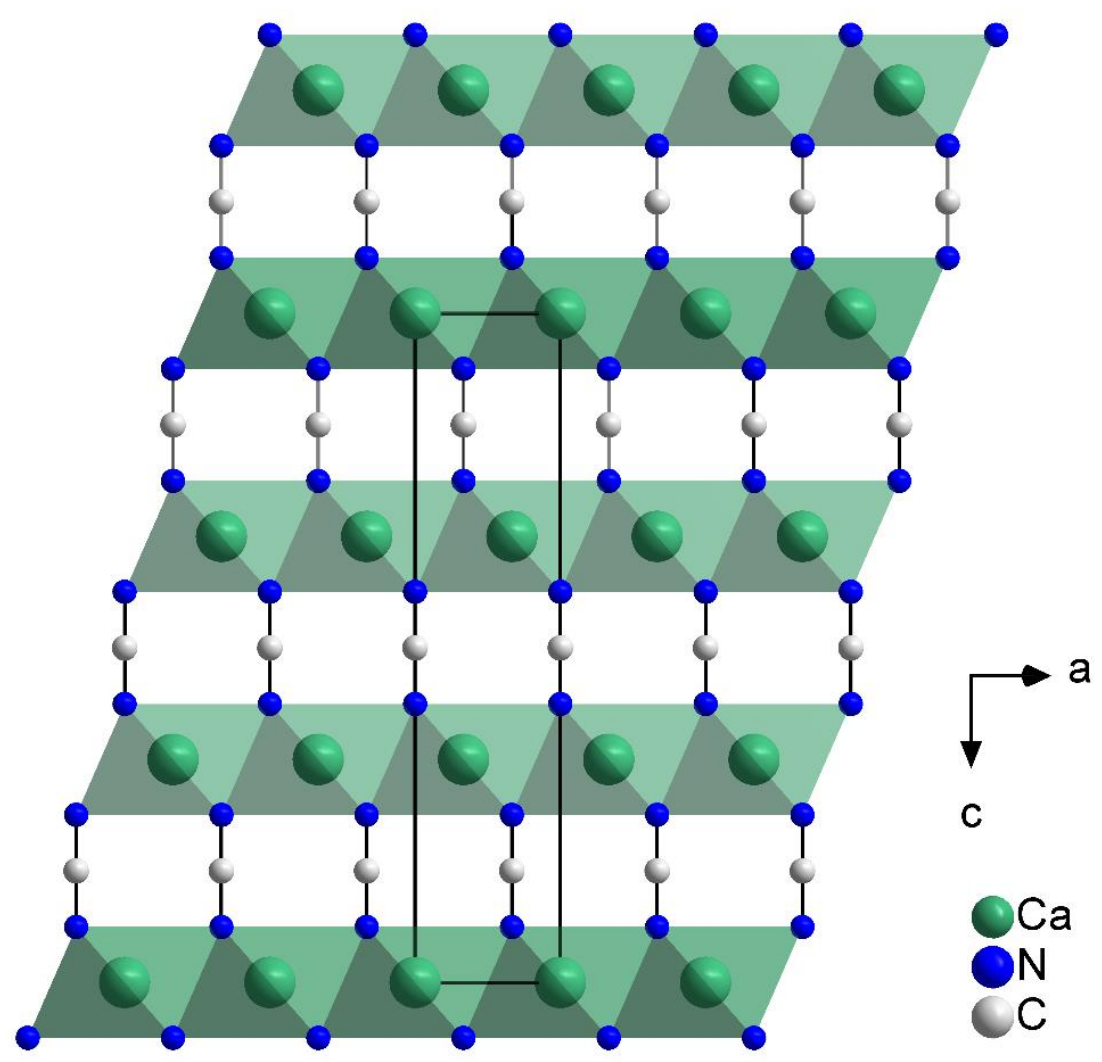

Figure 1. Crystal structure of $\mathrm{CaCN}_{2}$ with $\mathrm{CaN}_{6}$ octahedra drawn in light green, $\mathrm{Ca}$ atoms in green, $\mathrm{C}$ atoms in grey and $\mathrm{N}$ atoms in blue. 


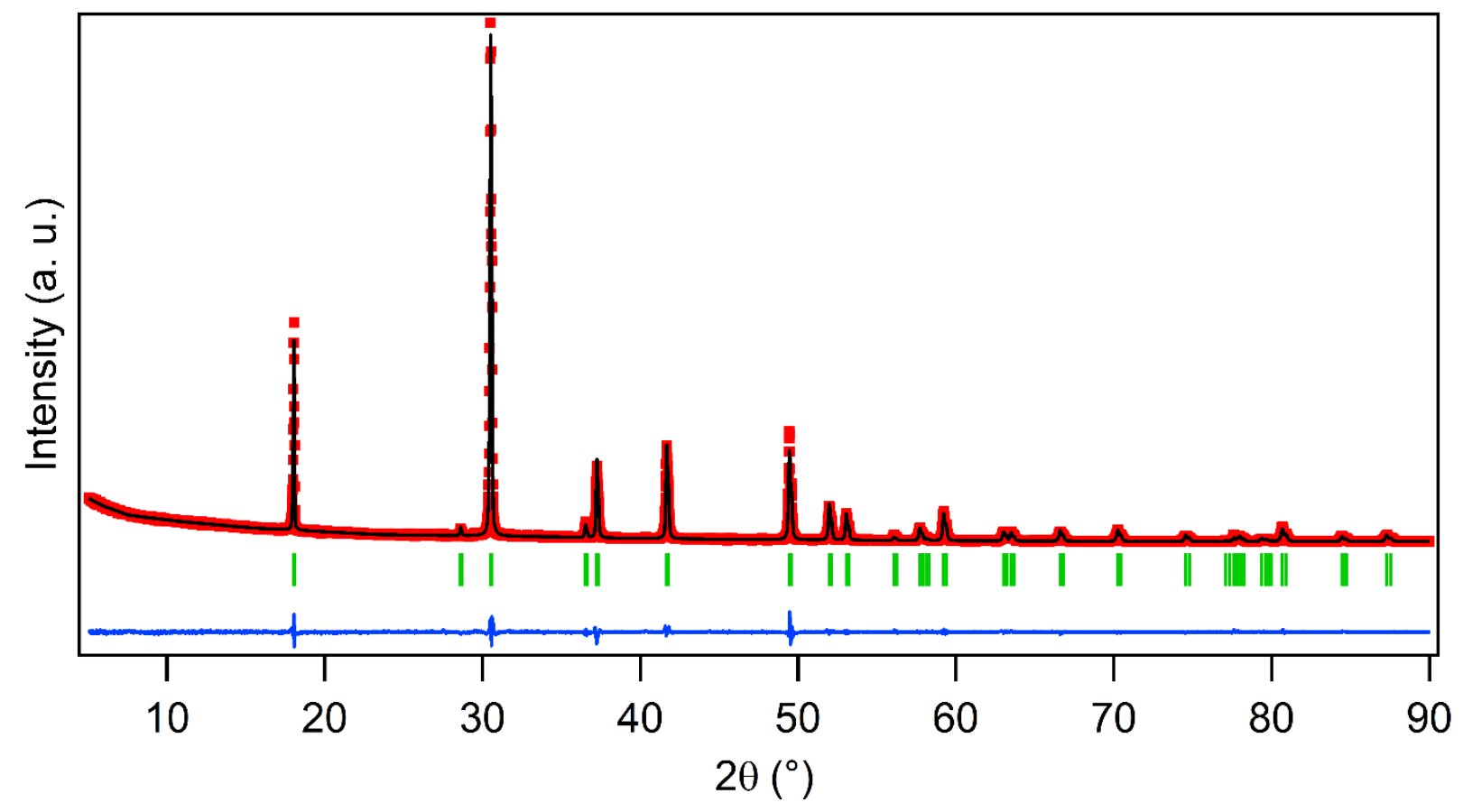

Figure 2. Final Rietveld refinement pattern for $\mathrm{Ca}_{0.96} \mathrm{Mn}_{0.04} \mathrm{CN}_{2}$ : observed (red dotted line), calculated (black full line) and difference (blue line) X-ray powder diffraction profiles from the pattern matching plot obtained with Fullprof. The vertical markers correspond to the position of the Bragg reflections. 


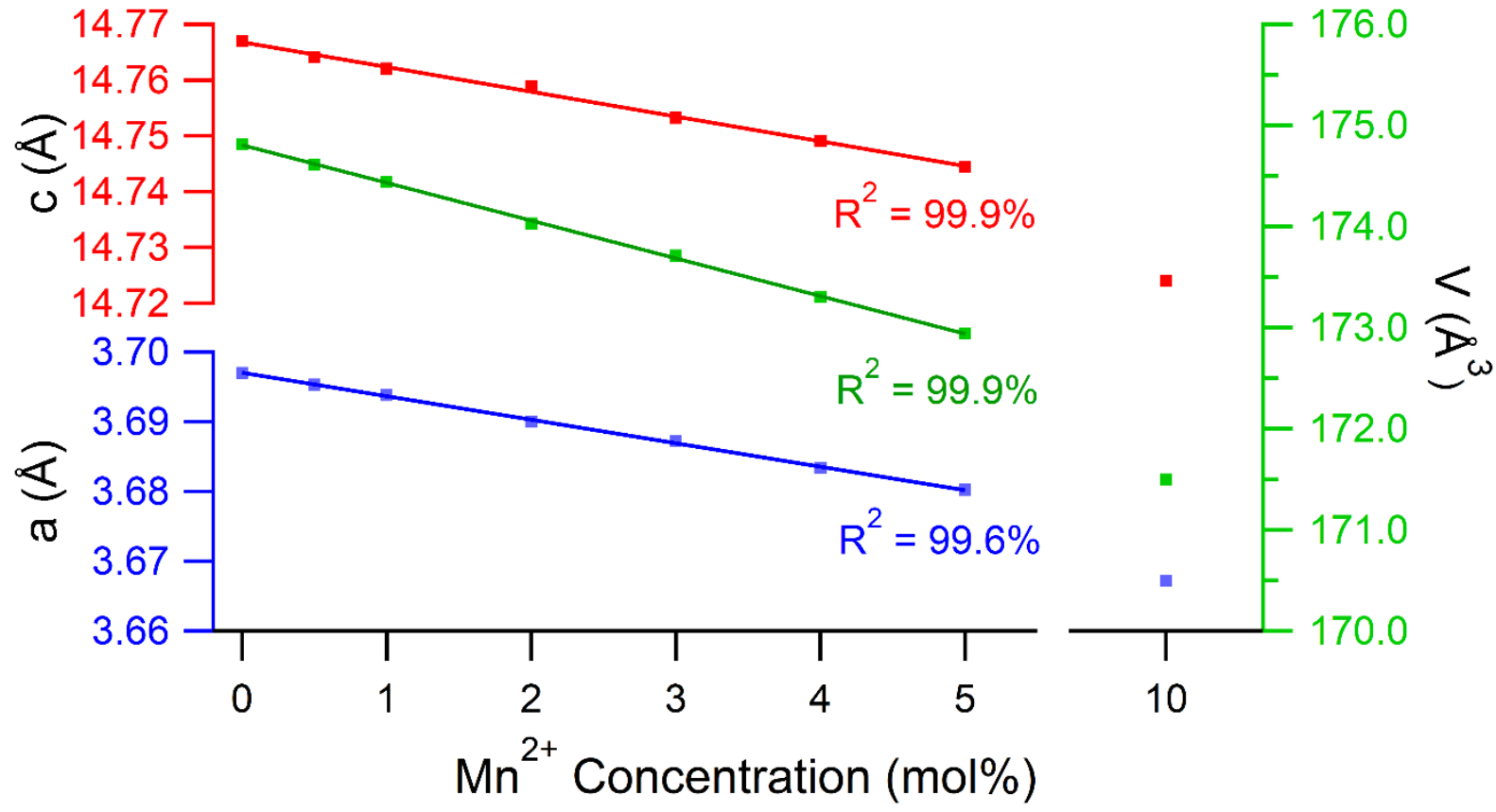

Figure 3. Evolution of the unit cell parameters $a, c$ and cell volume $V$ in $\mathrm{Ca}_{1-x} \mathrm{Mn}_{x} \mathrm{CN}_{2}(0<\mathrm{x}<0.1)$ samples versus $\mathrm{Mn}^{2+}$ doping concentration. 


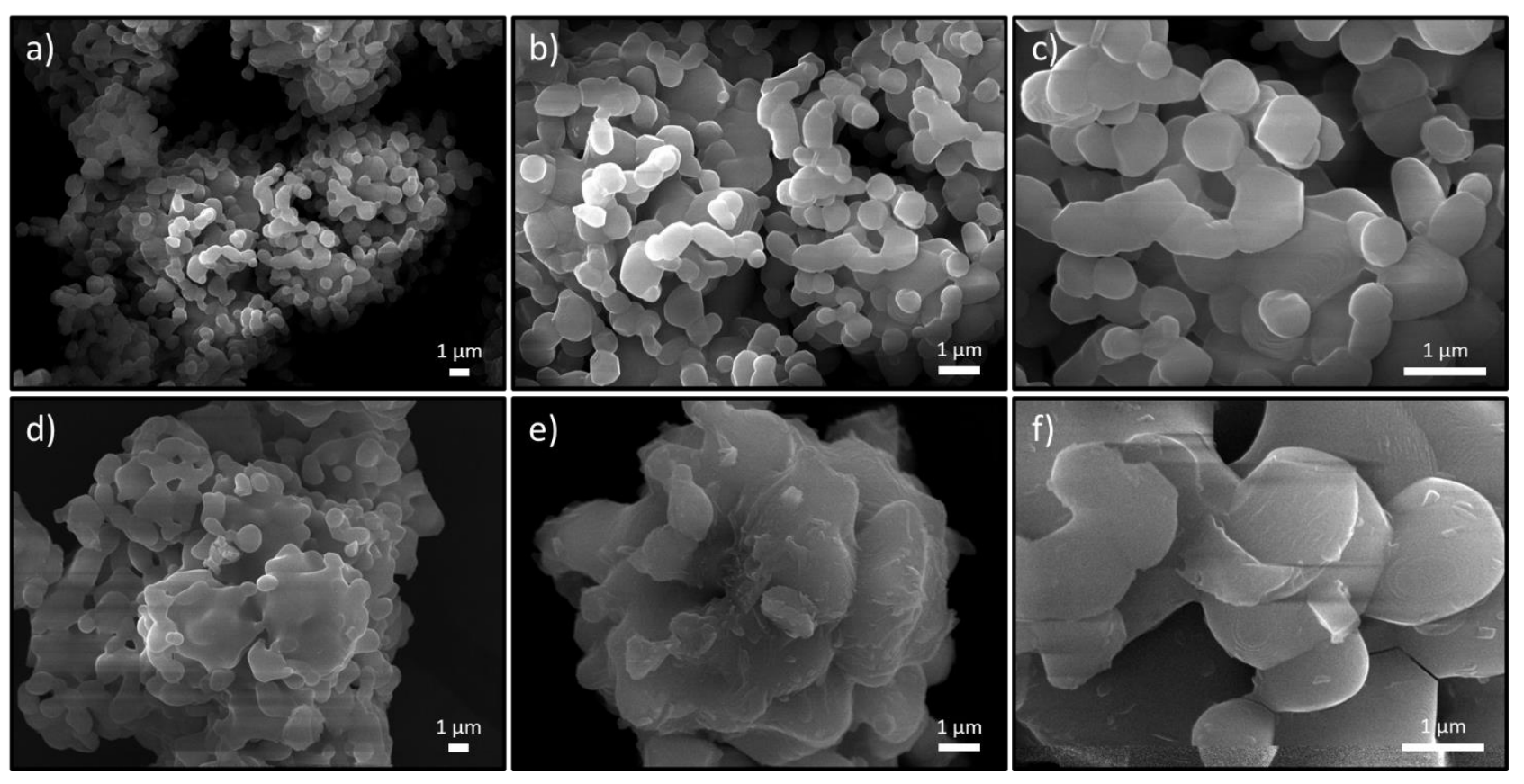

Figure 4. SEM images of (a-c) $\mathrm{CaCN}_{2}$ and (d-f) $\mathrm{Ca}_{0.96} \mathrm{Mn}_{0.04} \mathrm{CN}_{2}$ powders. 


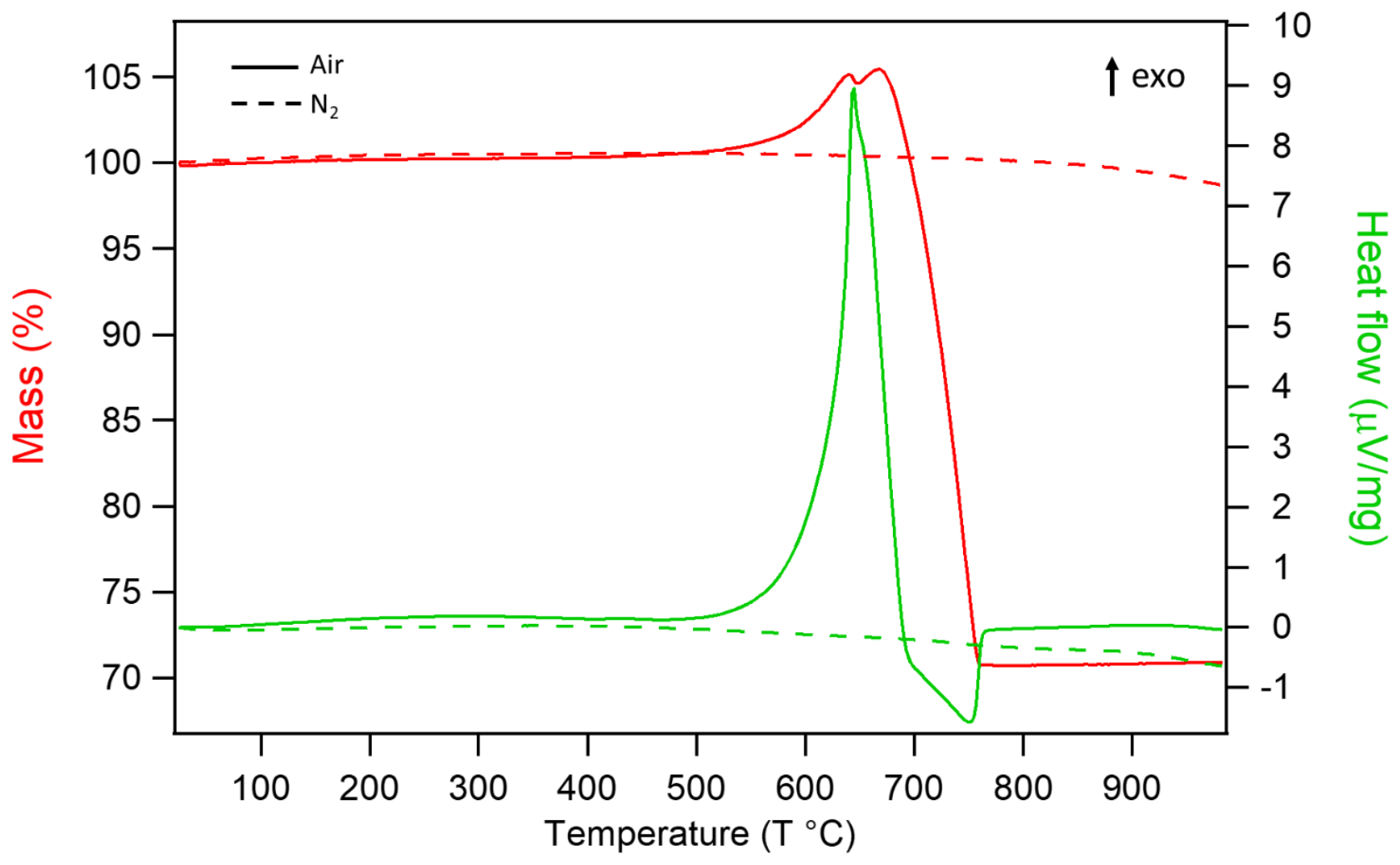

Figure 5. TGA and DSC curves of $\mathrm{CaCN}_{2}$ under air (full curves) and nitrogen (dashed curves). 


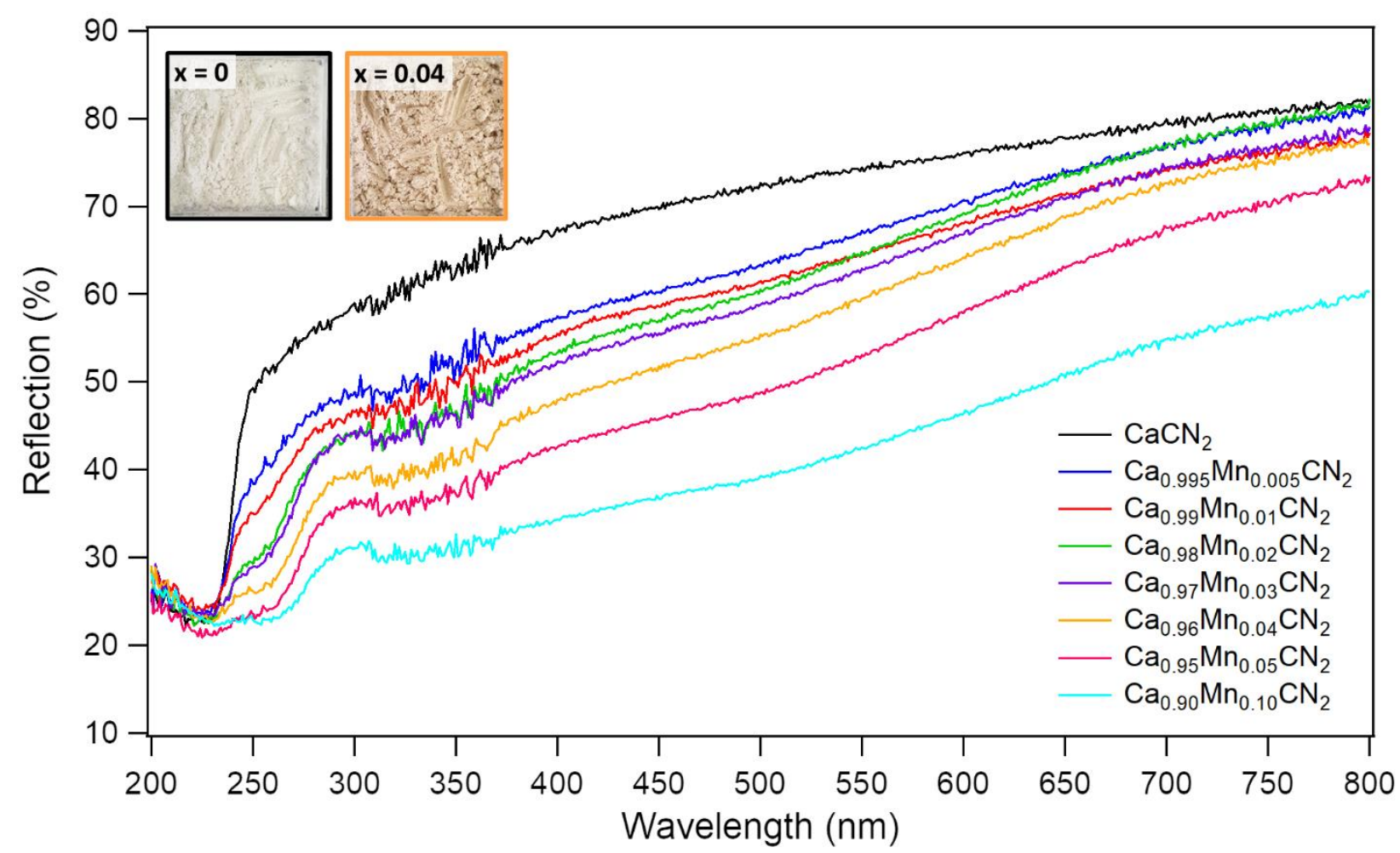

Figure 6. Solid-state diffuse reflection spectra of undoped and $\mathrm{Mn}^{2+}$-doped $\mathrm{CaCN}_{2}$ samples at room temperature. In inset: Appearance of $\mathrm{CaCN}_{2}$ and $\mathrm{Ca}_{0.96} \mathrm{Mn}_{0.04} \mathrm{CN}_{2}$ powders in daylight. 


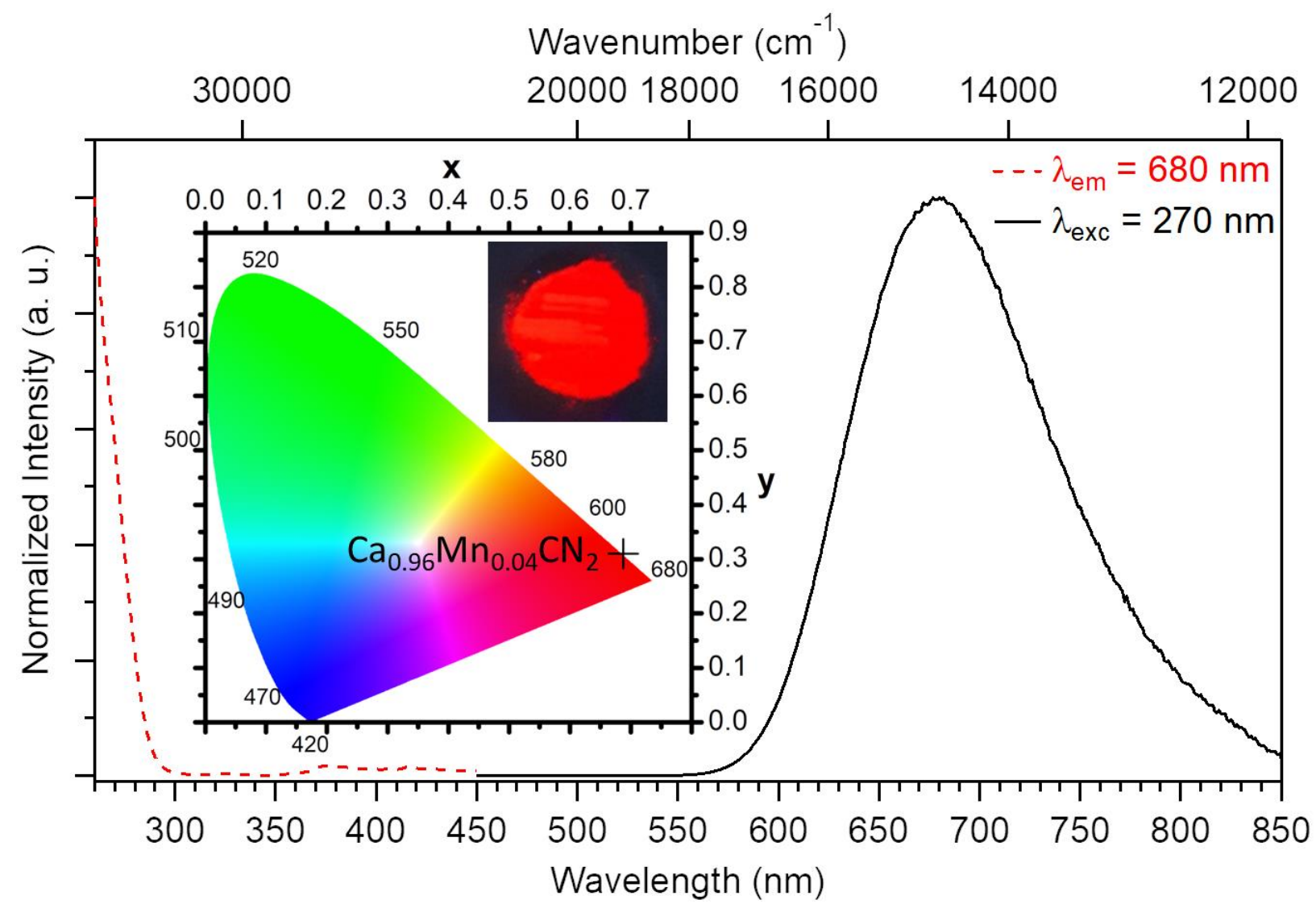

Figure 7. Solid-state excitation and emission spectra at room temperature of $\mathrm{Ca}_{0.96} \mathrm{Mn}_{0.04} \mathrm{CN}_{2}$. In inset: The CIE chromaticity diagram, chromaticity coordinates, and picture under $254 \mathrm{~nm}$ UV lamp. 
a

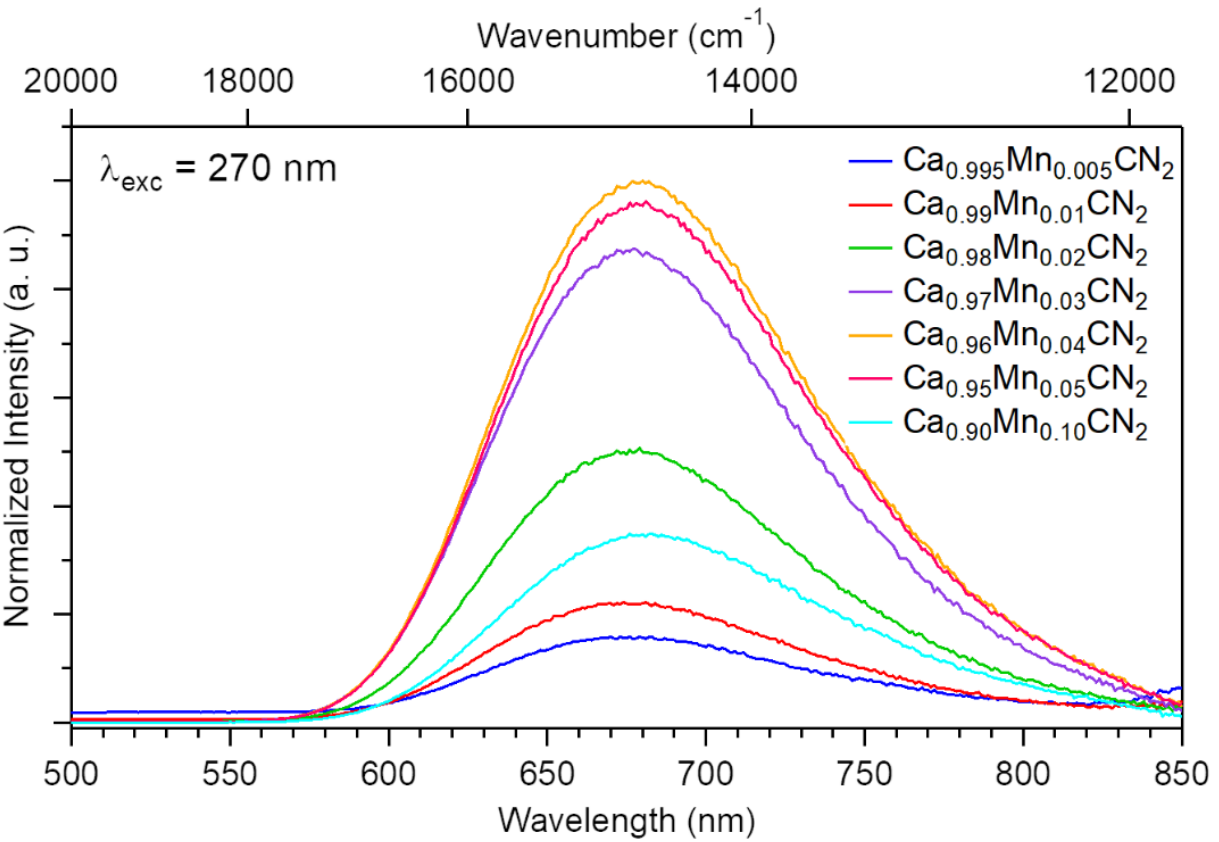

b

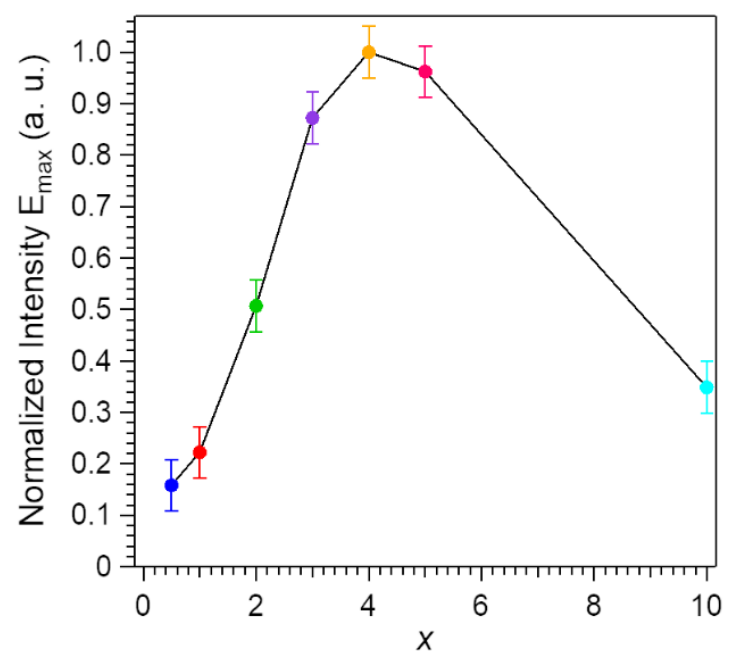

C

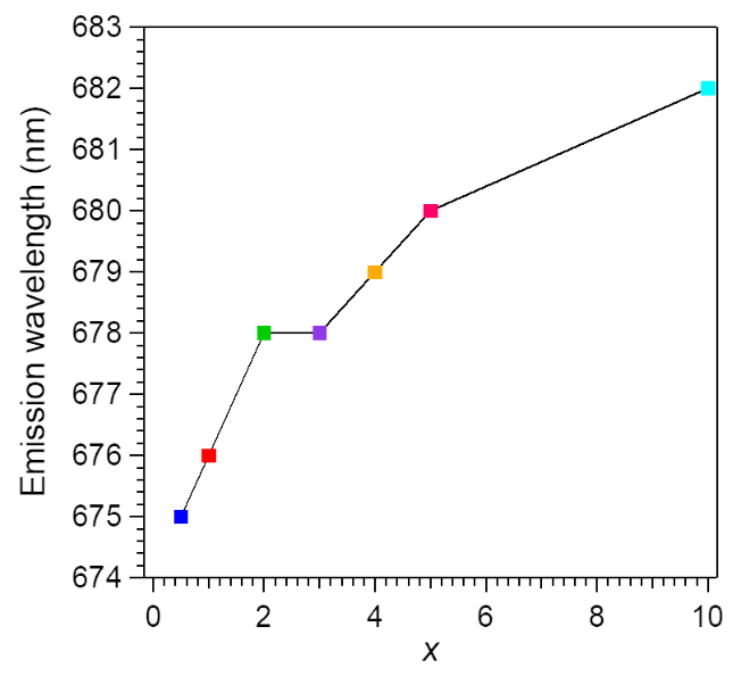

Figure 8. (a) Solid-state emission spectra at room temperature of $\mathrm{Ca}_{1-x} \mathrm{Mn}_{x} \mathrm{CN}_{2}(0<x<0.1)$ samples. (b) Normalized emission intensity $\left(\mathrm{E}_{\max }\right)$ vs $x(0 \leq x \leq 0.1)$ for $\mathrm{Ca}_{1-x} \mathrm{Mn}_{\mathrm{x}} \mathrm{CN}_{2}$. Uncertainty bars $= \pm 0.05$. (c) Dependance of emission wavelength on $\mathrm{Mn}^{2+}$ concentration. 
a

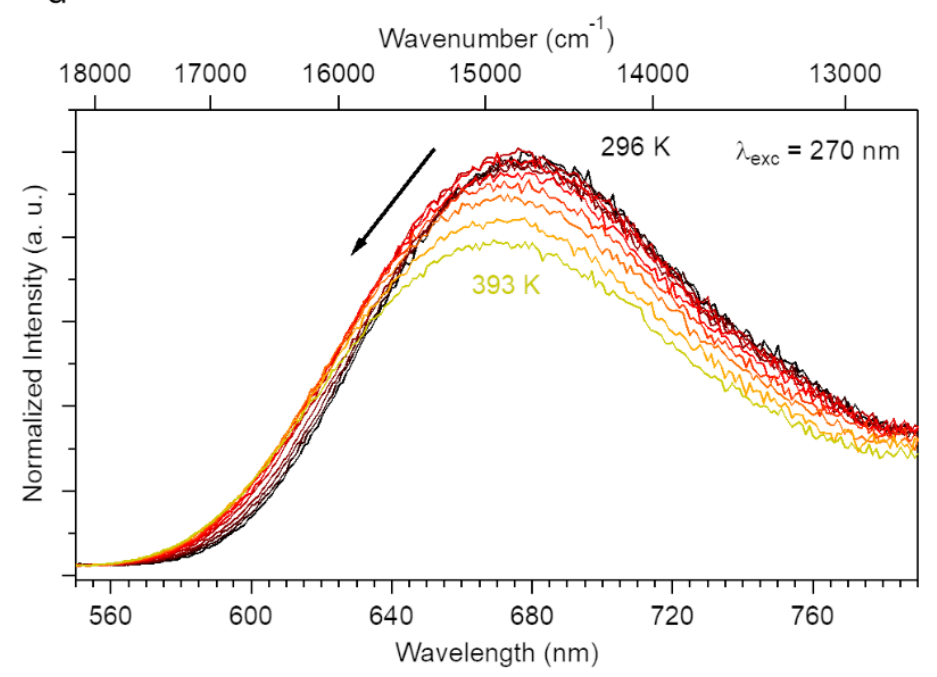

b

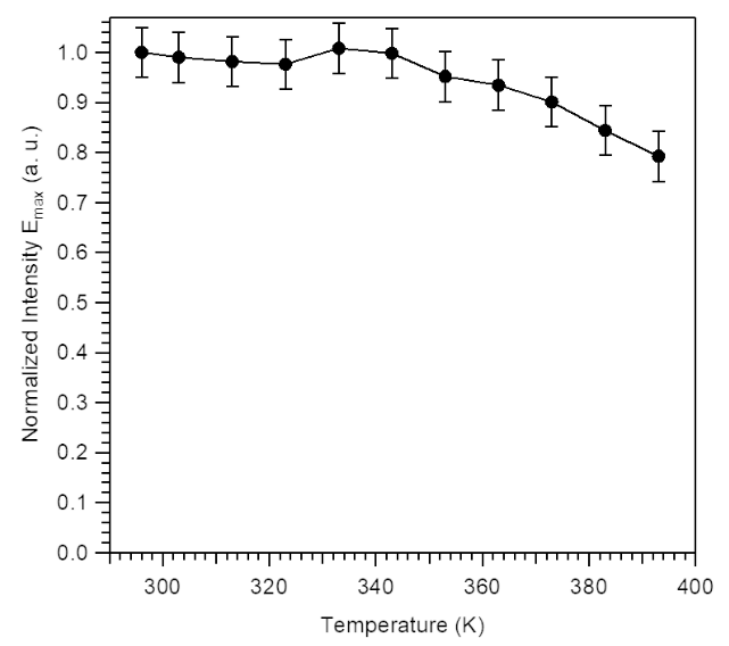

Figure 9. (a) Solid-state emission $\left(\lambda_{\mathrm{ex}}=270 \mathrm{~nm}\right)$ spectra of $\mathrm{Ca}_{0.96} \mathrm{Mn}_{0.04} \mathrm{CN}_{2}$ at variable temperature (296 - $393 \mathrm{~K})$. (b) Normalized emission intensity $\left(E_{\max }\right)$ vs temperature (296 - $393 \mathrm{~K}$ ) for $\mathrm{Ca}_{0.96} \mathrm{Mn}_{0.04} \mathrm{CN}_{2}$. Uncertainty bars $= \pm 0.05$. 
a

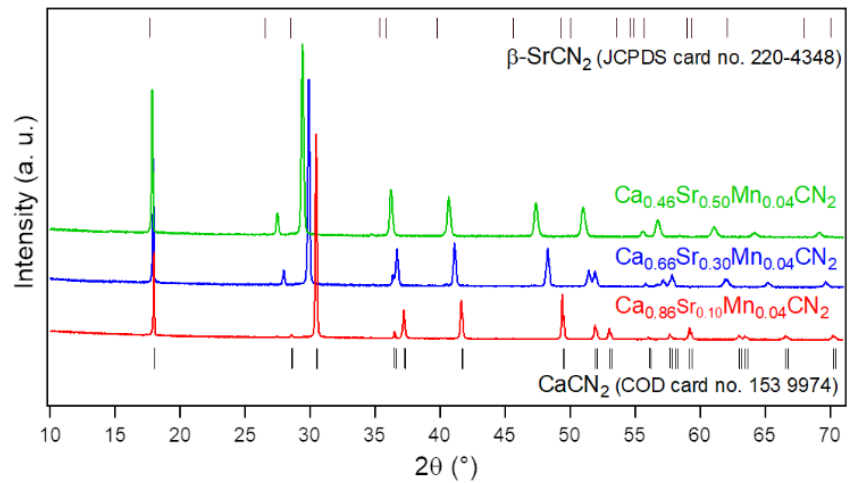

b

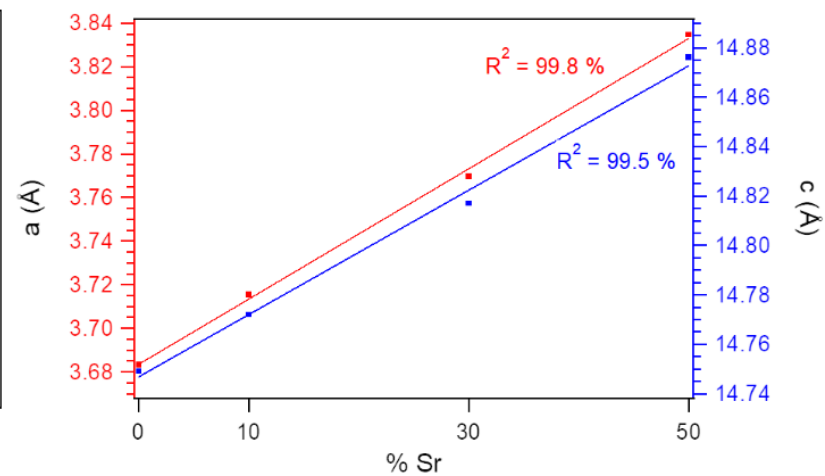

Figure 10. (a) Powder X-ray diffraction diagrams of $\mathrm{Ca}_{0.86} \mathrm{Sr}_{0.10} \mathrm{Mn}_{0.04} \mathrm{CN}_{2}, \mathrm{Ca}_{0.66} \mathrm{Sr}_{0.30} \mathrm{Mn}_{0.04} \mathrm{CN}_{2}$ and $\mathrm{Ca}_{0.46} \mathrm{Sr}_{0.50} \mathrm{Mn}_{0.04} \mathrm{CN}_{2}$ samples. (b) Evolution of the unit cell parameters $a, c$ and cell volume $V$ in $\mathrm{Ca}_{0.96-x} \mathrm{Sr}_{x} \mathrm{Mn}_{0.04} \mathrm{CN}_{2}(0<\mathrm{x}<0.5)$ samples as a function of $\mathrm{Sr}^{2+}$ doping concentration. 
a

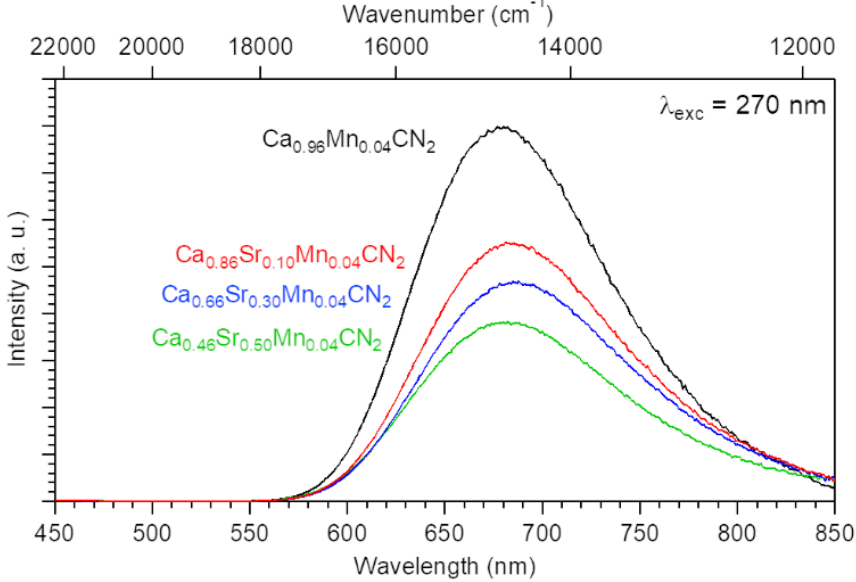

$b$

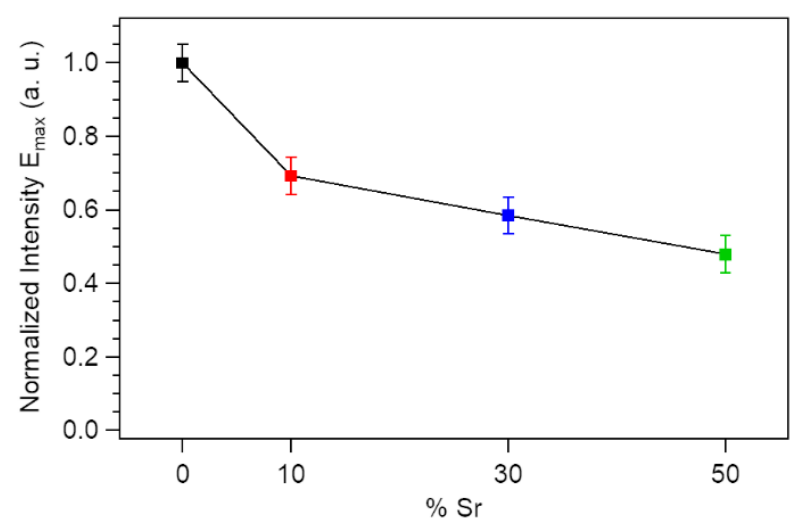

Figure 11. Solid-state emission spectra at room temperature of $\mathrm{Ca}_{0.86} \mathrm{Sr}_{0.10} \mathrm{Mn}_{0.04} \mathrm{CN}_{2}$, $\mathrm{Ca}_{0.66} \mathrm{Sr}_{0.30} \mathrm{Mn}_{0.04} \mathrm{CN}_{2}$ and $\mathrm{Ca}_{0.46} \mathrm{Sr}_{0.50} \mathrm{Mn}_{0.04} \mathrm{CN}_{2}$ samples. (b) Normalized emission intensity ( $\mathrm{E}_{\text {max }}$ ) vs $x$ $(0 \leq x \leq 0.5)$ for $\mathrm{Ca}_{0.96-x} \mathrm{Sr}_{x} \mathrm{Mn}_{0.04} \mathrm{CN}_{2}$. Uncertainty bars $= \pm 0.05$. 


\section{Supporting information}

\section{Synthesis and photoluminescence properties of $\mathrm{Mn}^{2+}$ doped $\mathrm{Ca}_{1-\mathrm{x}} \mathrm{Sr}_{\mathrm{x}} \mathrm{CN}_{2}$ phosphors prepared by a carbon nitride based route}

Erwan Leysour de Rohello, Yan Suffren, Odile Merdrignac-Conanec, Olivier Guillou, Christophe Calers, François Cheviré*

Univ Rennes 1, INSA Rennes, CNRS, ISCR (Institut des Sciences chimiques de Rennes) - UMR 6226, F-35000 Rennes, France

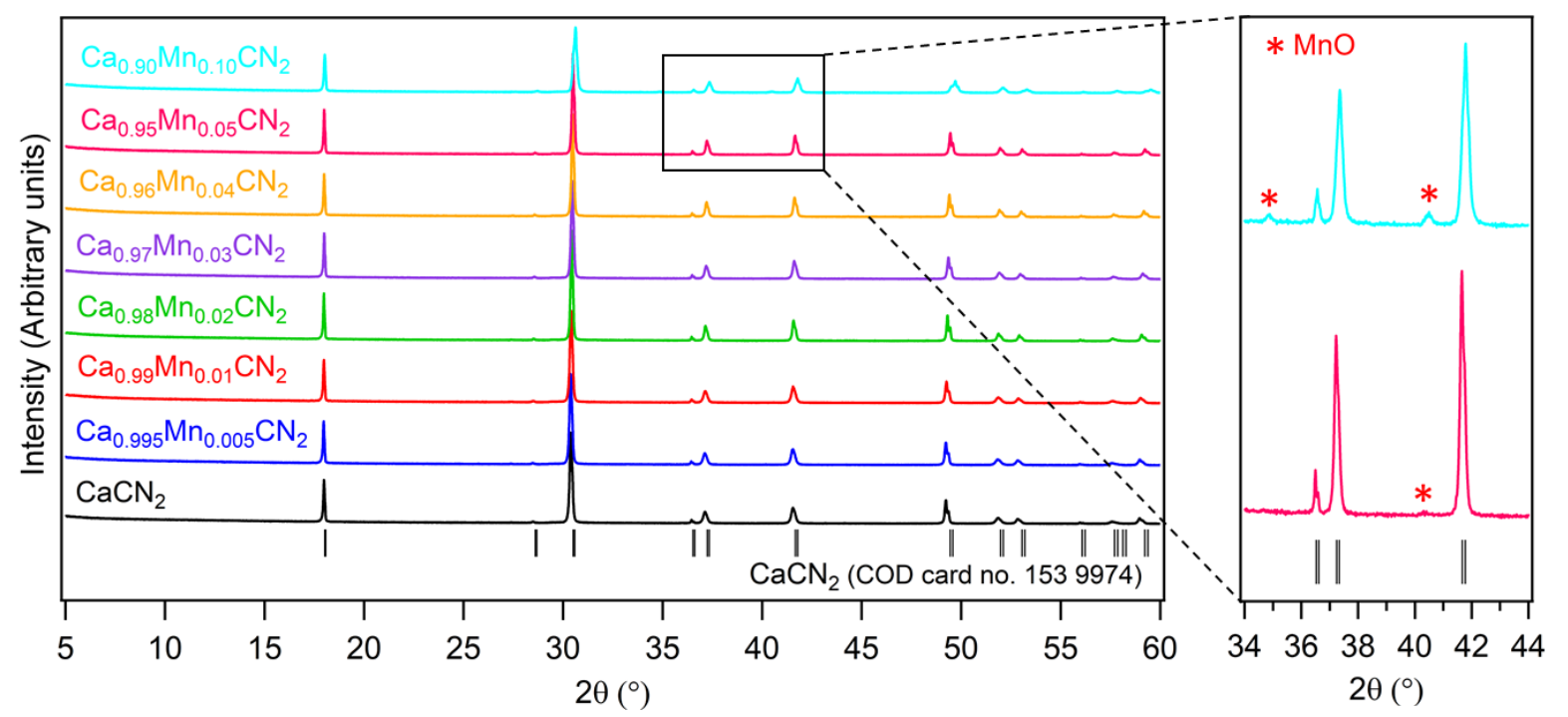

Figure S1. Powder X-ray diffraction diagrams of $\mathrm{Ca}_{1-x} \mathrm{Mn}_{x} \mathrm{CN}_{2}(0 \leq x \leq 0.1)$ samples. Inset: Zoom on the $X$-ray diffraction diagrams of samples $\mathrm{Ca}_{0.95} \mathrm{Mn}_{0.05} \mathrm{CN}_{2}$ and $\mathrm{Ca}_{0.90} \mathrm{Mn}_{0.10} \mathrm{CN}_{2}$ between $34^{\circ}$ and $44^{\circ}$. 


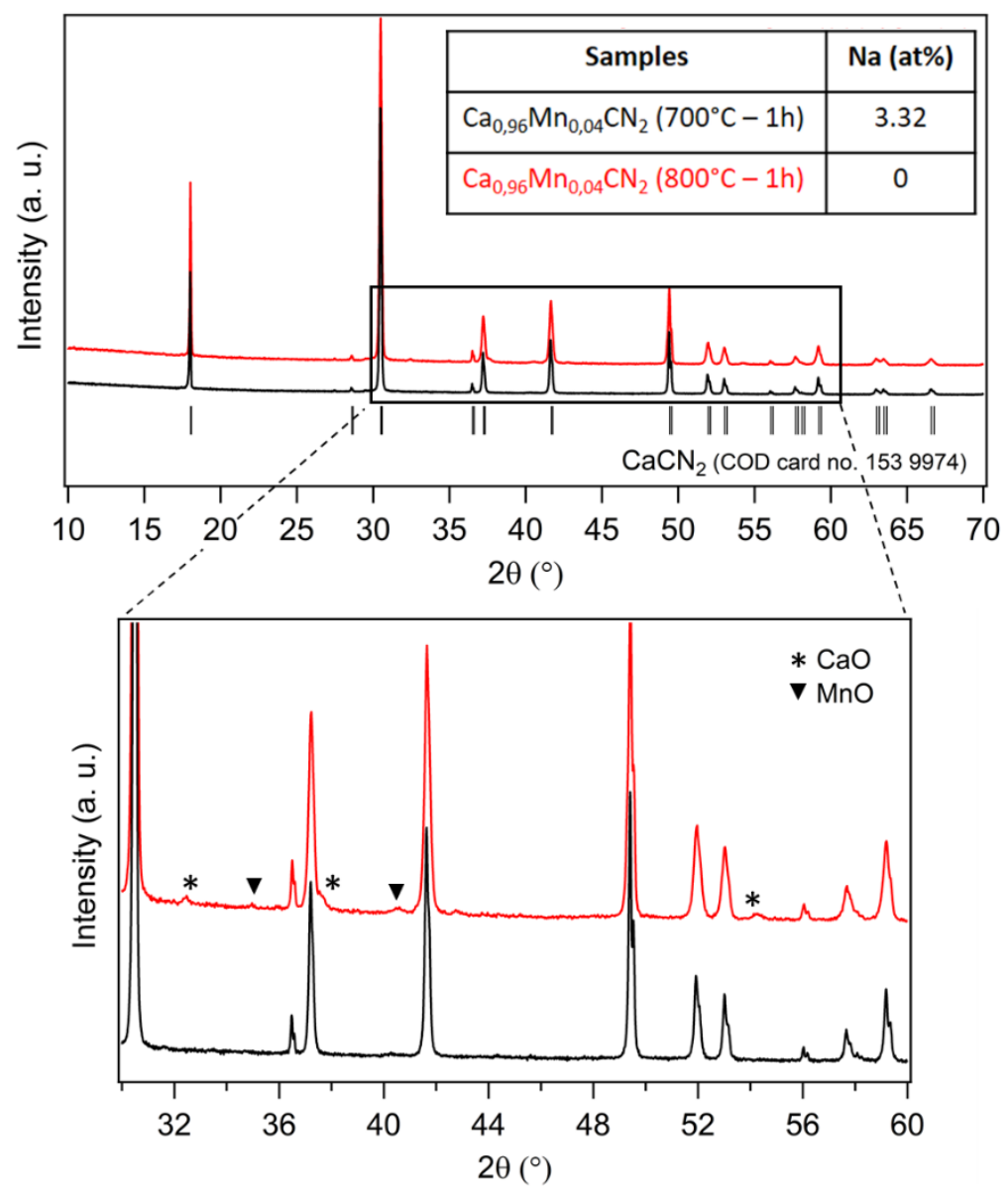

Figure S2. Powder X-ray diffraction diagrams of $\mathrm{Ca}_{0.96} \mathrm{Mn}_{0.04} \mathrm{CN}_{2}$ sample synthesized at $700{ }^{\circ} \mathrm{C}$ and $800{ }^{\circ} \mathrm{C}$ for $1 \mathrm{~h}$. Inset: Zoom on the X-ray diffraction diagrams of samples $\mathrm{Ca}_{0.95} \mathrm{Mn}_{0.05} \mathrm{CN}_{2}$ and $\mathrm{Ca}_{0.90} \mathrm{Mn}_{0.10} \mathrm{CN}_{2}$ between $30^{\circ}$ and $60^{\circ}$.

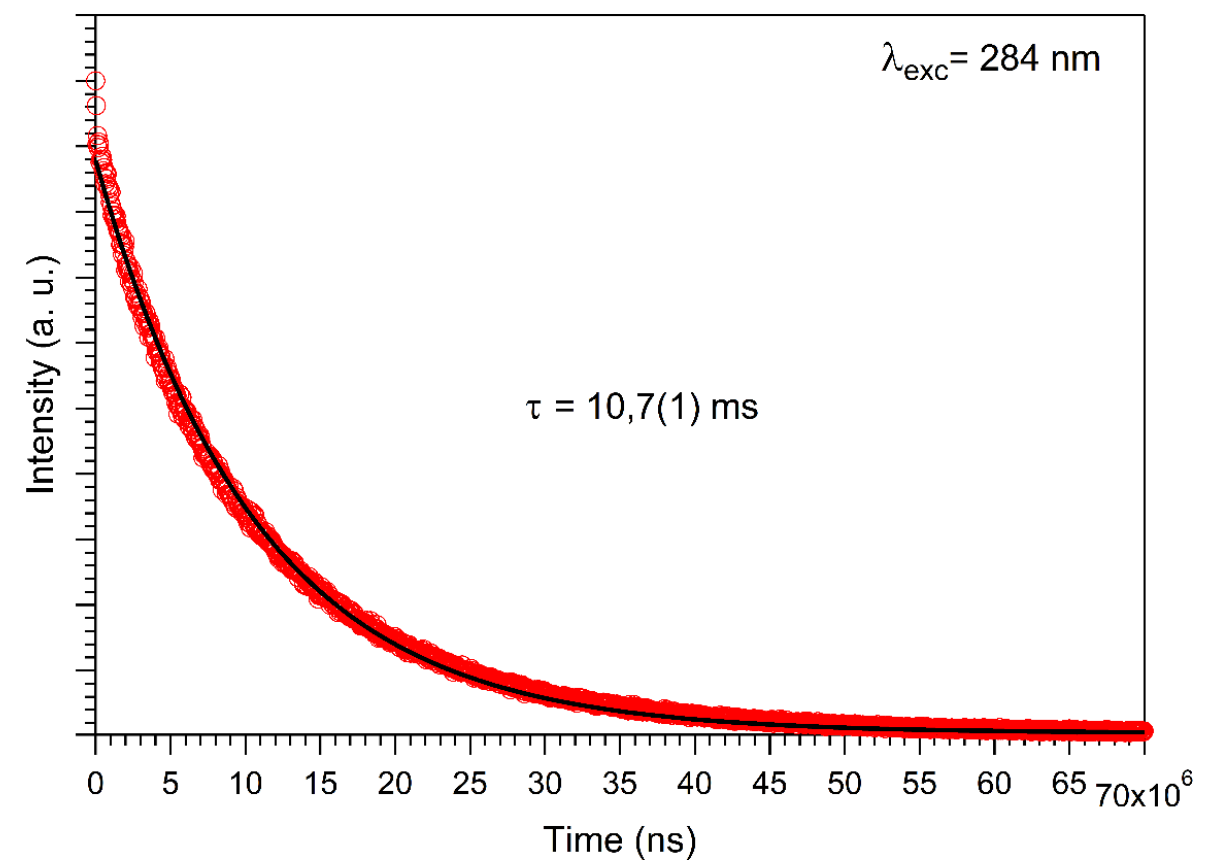

Figure S3. Luminescent decay measurement of $\mathrm{Ca}_{0.96} \mathrm{Mn}_{0.04} \mathrm{CN}_{2}$ at $300 \mathrm{~K}$ under photo-excitation at $284 \mathrm{~nm}$ 


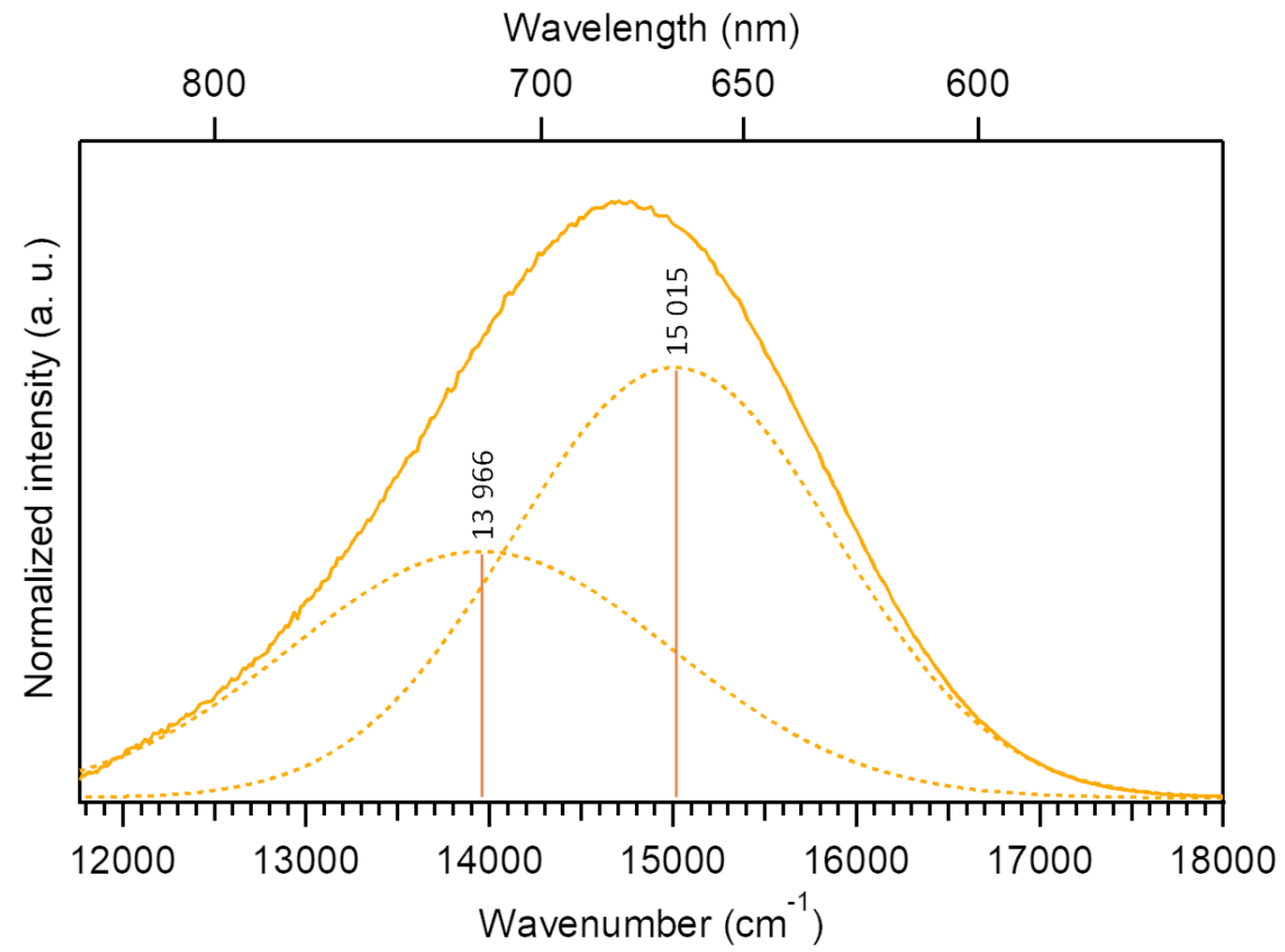

Figure S4. Solid-state emission spectra (solid) and decomposed Gaussian components (dotted) at room temperature of $\mathrm{Ca}_{0.96} \mathrm{Mn}_{0.04} \mathrm{CN}_{2}$

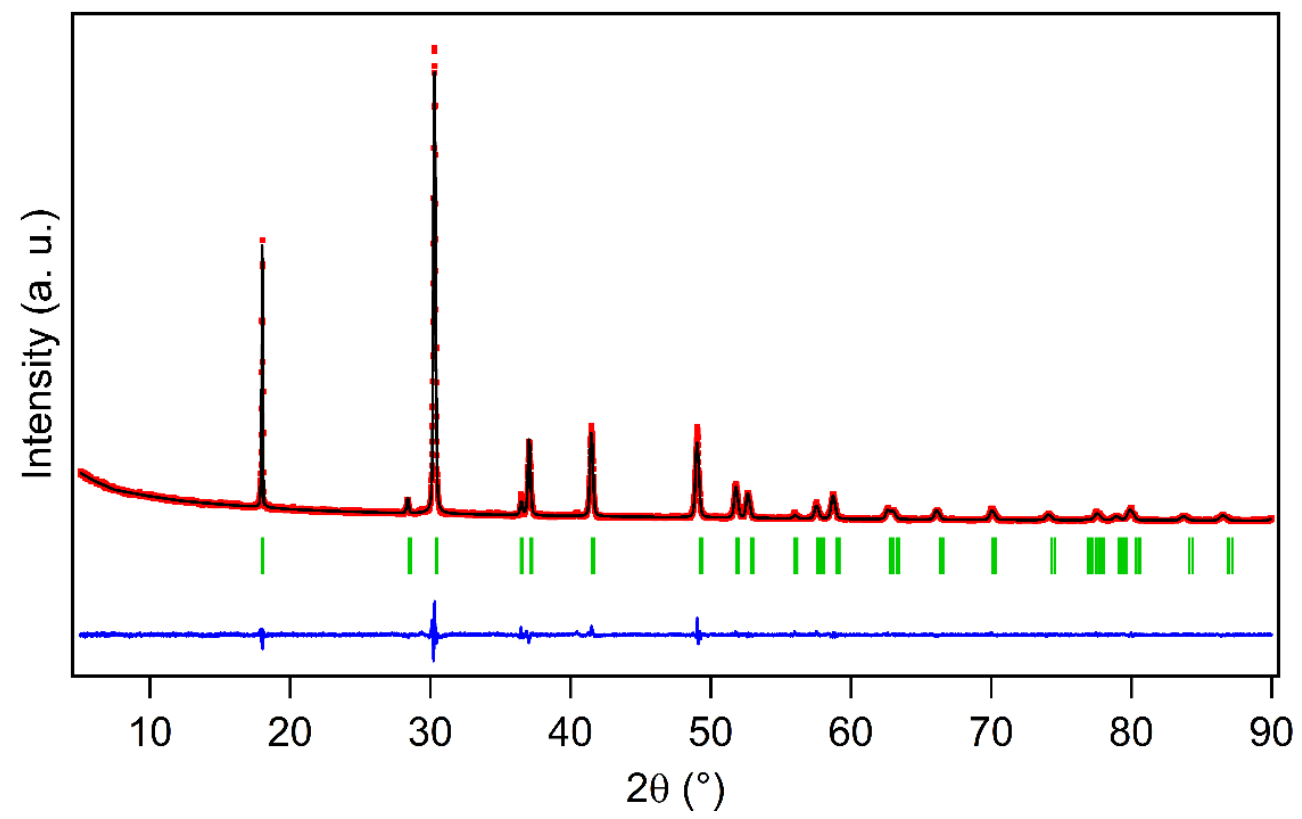

Figure S5. Final Rietveld refinement pattern for $\mathrm{Ca}_{0.86} \mathrm{Sr}_{0.10} \mathrm{Mn}_{0.04} \mathrm{CN}_{2}$ : observed (red dotted line), calculated (black full line) and difference (blue line) X-ray powder diffraction profiles from the pattern matching plot obtained with Fullprof. The vertical markers correspond to the position of the Bragg reflections. 


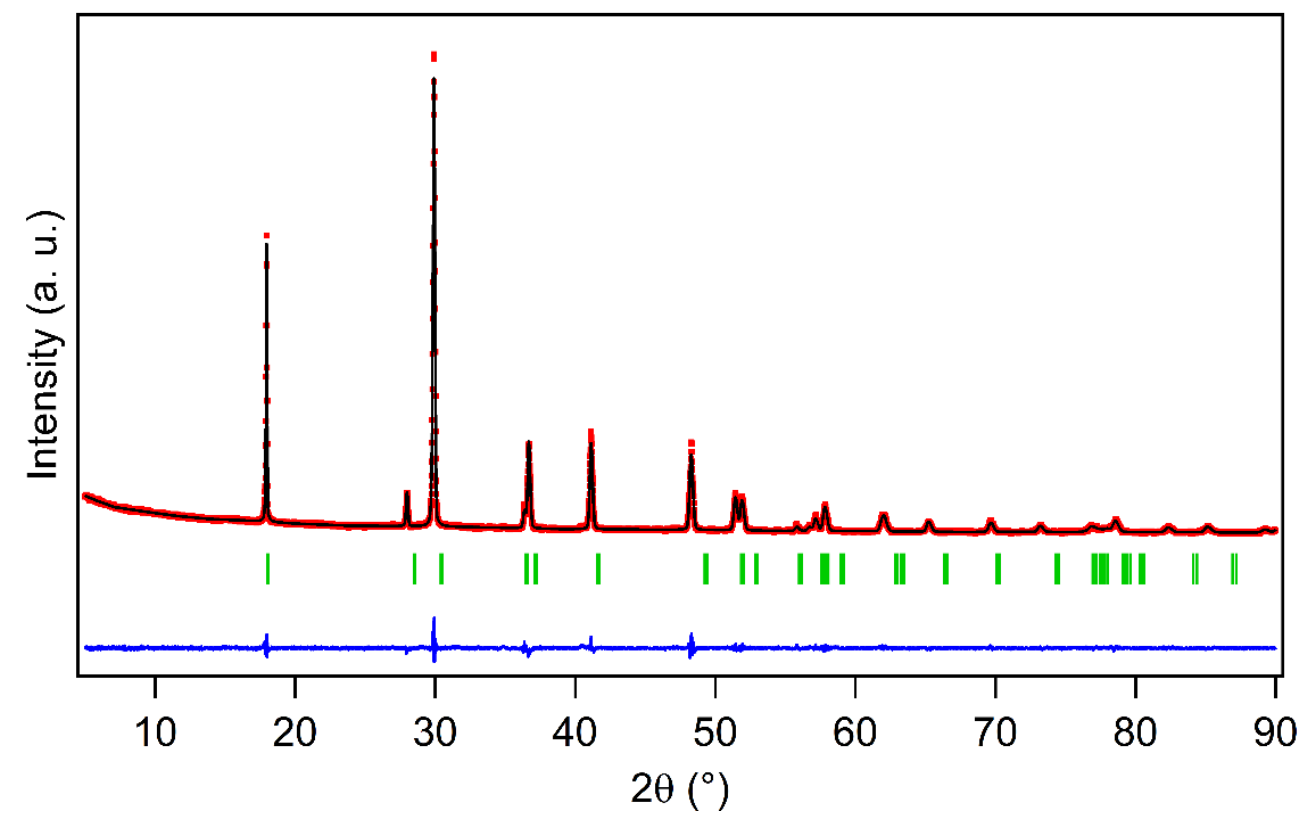

Figure S6. Final Rietveld refinement pattern for $\mathrm{Ca}_{0.66} \mathrm{Sr}_{0.30} \mathrm{Mn}_{0.04} \mathrm{CN}_{2}$ : observed (red dotted line), calculated (black full line) and difference (blue line) X-ray powder diffraction profiles from the pattern matching plot obtained with Fullprof. The vertical markers correspond to the position of the Bragg reflections.

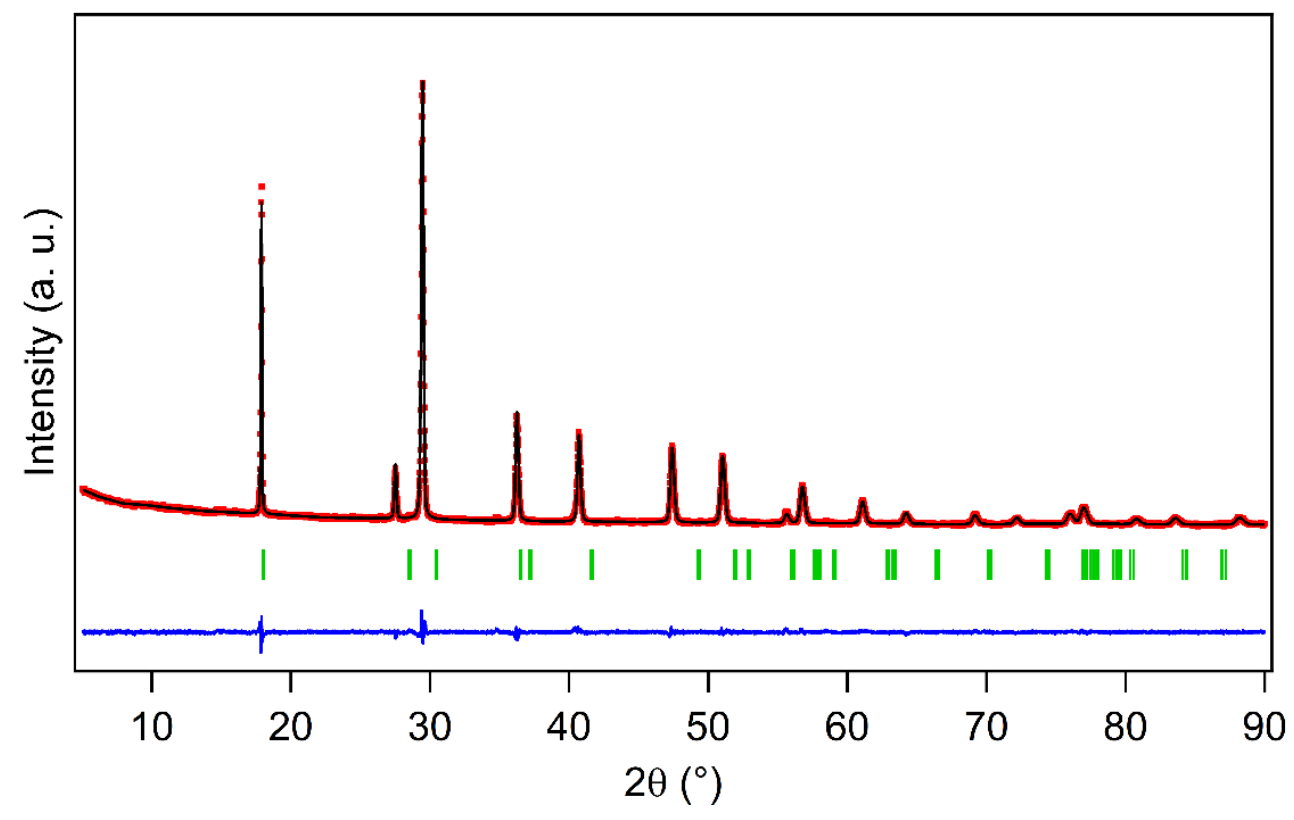

Figure S7. Final Rietveld refinement pattern for $\mathrm{Ca}_{0.46} \mathrm{Sr}_{0.50} \mathrm{Mn}_{0.04} \mathrm{CN}_{2}$ : observed (red dotted line), calculated (black full line) and difference (blue line) X-ray powder diffraction profiles from the pattern matching plot obtained with Fullprof. The vertical markers correspond to the position of the Bragg reflections. 
Table S1. Occupied Wyckoff sites, refined atomic coordinates (in $\AA$ ), isotropic atomic displacement parameters $B_{\text {iso }}$ (in $\AA^{2}$ ) and site occupancies of $\mathrm{Ca}_{1-\mathrm{x}} \mathrm{Mn}_{x} \mathrm{CN}_{2}$ samples (standard deviation in parentheses).

\begin{tabular}{|c|c|c|c|c|c|c|}
\hline & Position & $x$ & $y$ & $z$ & $B_{i s o}\left(\AA^{2}\right)$ & Occupancy \\
\hline \multicolumn{7}{|c|}{$\mathrm{CaCN}_{2}$} \\
\hline $\mathrm{Ca}$ & $3 b$ & 0 & 0 & 0 & $0.88(8)$ & 1 \\
\hline$C$ & $3 a$ & 0 & 0 & 0.5 & $0.8(2)$ & 1 \\
\hline$N$ & $6 c$ & 0 & 0 & $0.4162(3)$ & $0.8(1)$ & 1 \\
\hline \multicolumn{7}{|c|}{$\mathrm{Ca}_{0.995} \mathrm{Mn}_{0.005} \mathrm{CN}_{2}$} \\
\hline $\mathrm{Ca}$ & $3 b$ & 0 & 0 & 0 & $0.82(8)$ & 0.998 \\
\hline$M n$ & $3 b$ & 0 & 0 & 0 & $0.82(8)$ & 0.005 \\
\hline$C$ & $3 a$ & 0 & 0 & 0.5 & $0.8(2)$ & 1 \\
\hline$N$ & $6 c$ & 0 & 0 & $0.4162(3)$ & $0.8(1)$ & 1 \\
\hline \multicolumn{7}{|c|}{$\mathrm{Ca}_{0.99} \mathrm{Mn}_{0.01} \mathrm{CN}_{2}$} \\
\hline $\mathrm{Ca}$ & $3 b$ & 0 & 0 & 0 & $0.87(8)$ & 0.99 \\
\hline$M n$ & $3 b$ & 0 & 0 & 0 & $0.87(8)$ & 0.01 \\
\hline$C$ & $3 a$ & 0 & 0 & 0.5 & $0.7(2)$ & 1 \\
\hline$N$ & $6 c$ & 0 & 0 & $0.4165(3)$ & $0.7(1)$ & 1 \\
\hline \multicolumn{7}{|c|}{$\mathrm{Ca}_{0.98} \mathrm{Mn}_{0.02} \mathrm{CN}_{2}$} \\
\hline $\mathrm{Ca}$ & $3 b$ & 0 & 0 & 0 & $0.81(6)$ & 0.98 \\
\hline$M n$ & $3 b$ & 0 & 0 & 0 & $0.81(6)$ & 0.02 \\
\hline C & $3 a$ & 0 & 0 & 0.5 & $0.6(2)$ & 1 \\
\hline$N$ & $6 c$ & 0 & 0 & $0.4165(2)$ & $0.7(1)$ & 1 \\
\hline \multicolumn{7}{|c|}{$\mathrm{Ca}_{0.97} \mathrm{Mn}_{0.03} \mathrm{CN}_{2}$} \\
\hline $\mathrm{Ca}$ & $3 b$ & 0 & 0 & 0 & $0.91(6)$ & 0.97 \\
\hline$M n$ & $3 b$ & 0 & 0 & 0 & $0.91(6)$ & 0.03 \\
\hline c & $3 a$ & 0 & 0 & 0.5 & $0.6(2)$ & 1 \\
\hline$N$ & $6 c$ & 0 & 0 & $0.4165(2)$ & $0.7(1)$ & 1 \\
\hline \multicolumn{7}{|c|}{$\mathrm{Ca} a_{0.96} \mathrm{Mn}_{0.04} \mathrm{CN}_{2}$} \\
\hline $\mathrm{Ca}$ & $3 b$ & 0 & 0 & 0 & $0.78(5)$ & 0.96 \\
\hline$M n$ & $3 b$ & 0 & 0 & 0 & $0.78(5)$ & 0.04 \\
\hline$C$ & $3 a$ & 0 & 0 & 0.5 & $0.5(1)$ & 1 \\
\hline$N$ & $6 c$ & 0 & 0 & $0.4168(2)$ & $0.68(9)$ & 1 \\
\hline \multicolumn{7}{|c|}{$\mathrm{Ca}_{0.95} \mathrm{Mn}_{0.05} \mathrm{CN}_{2}$} \\
\hline $\mathrm{Ca}$ & $3 b$ & 0 & 0 & 0 & $0.79(6)$ & 0.95 \\
\hline$M n$ & $3 b$ & 0 & 0 & 0 & $0.79(6)$ & 0.05 \\
\hline C & $3 a$ & 0 & 0 & 0.5 & $0.5(1)$ & 1 \\
\hline$N$ & $6 c$ & 0 & 0 & $0.4163(2)$ & $0.5(1)$ & 1 \\
\hline \multicolumn{7}{|c|}{$\mathrm{Ca}_{0.90} \mathrm{Mn}_{0.10} \mathrm{CN}_{2}$} \\
\hline $\mathrm{Ca}$ & $3 b$ & 0 & 0 & 0 & $1.0(1)$ & 0.90 \\
\hline$M n$ & $3 b$ & 0 & 0 & 0 & $1.0(1)$ & 0.10 \\
\hline$C$ & $3 a$ & 0 & 0 & 0.5 & $0.8(2)$ & 1 \\
\hline$N$ & $6 c$ & 0 & 0 & $0.4170(2)$ & $0.8(2)$ & 1 \\
\hline
\end{tabular}


Table S2. Occupied Wyckoff sites, refined atomic coordinates (in $\AA$ ), isotropic atomic displacement parameters $B_{\text {iso }}$ (in $\AA^{2}$ ) and site occupancies of $\mathrm{Ca}_{0.86} \mathrm{Sr}_{0.10} \mathrm{Mn}_{0.04} \mathrm{CN}_{2}, \mathrm{Ca}_{0.66} \mathrm{Sr}_{0.30} \mathrm{Mn}_{0.04} \mathrm{CN}_{2}$ and $\mathrm{Ca}_{0.46} \mathrm{Sr}_{0.50} \mathrm{Mn}_{0.04} \mathrm{CN}_{2}$ samples (standard deviation in parentheses).

\begin{tabular}{|c|c|c|c|c|c|c|}
\hline Atome & Position & $x$ & $y$ & $z$ & $B_{\text {iso }}\left(\AA^{2}\right)$ & Occupation \\
\hline \multicolumn{7}{|c|}{$\mathrm{Ca}_{0.86} \mathrm{Sr}_{0.10} \mathrm{Mn}_{0.04} \mathrm{CN}_{2}$} \\
\hline $\mathrm{Ca}$ & $3 b$ & 0 & 0 & 0 & $1.08(2)$ & 0.86 \\
\hline$S r$ & $3 b$ & 0 & 0 & 0 & $1.08(2)$ & 0.10 \\
\hline$M n$ & $3 b$ & 0 & 0 & 0 & $1.08(2)$ & 0.04 \\
\hline C & $3 a$ & 0 & 0 & 0.5 & $0.62(8)$ & 1 \\
\hline$N$ & $6 c$ & 0 & 0 & $0.4169(3)$ & $0.9(1)$ & 1 \\
\hline \multicolumn{7}{|c|}{$\mathrm{Ca}_{0.66} \mathrm{Sr}_{0.30} \mathrm{Mn}_{0.04} \mathrm{CN}_{2}$} \\
\hline $\mathrm{Ca}$ & $3 b$ & 0 & 0 & 0 & $1.44(2)$ & 0.66 \\
\hline$S r$ & $3 b$ & 0 & 0 & 0 & $1.44(2)$ & 0.30 \\
\hline$M n$ & $3 b$ & 0 & 0 & 0 & $1.44(2)$ & 0.04 \\
\hline$c$ & $3 a$ & 0 & 0 & 0.5 & $1.2(2)$ & 1 \\
\hline$N$ & $6 c$ & 0 & 0 & $0.4177(3)$ & $1.3(1)$ & 1 \\
\hline \multicolumn{7}{|c|}{$\mathrm{Ca}_{0.46} \mathrm{Sr}_{0.50} \mathrm{Mn}_{0.04} \mathrm{CN}_{2}$} \\
\hline $\mathrm{Ca}$ & $3 b$ & 0 & 0 & 0 & $1.28(7)$ & 0.46 \\
\hline$S r$ & $3 b$ & 0 & 0 & 0 & $1.28(7)$ & 0.50 \\
\hline$M n$ & $3 b$ & 0 & 0 & 0 & $1.28(7)$ & 0.04 \\
\hline$c$ & $3 a$ & 0 & 0 & 0.5 & $1.4(2)$ & 1 \\
\hline$N$ & $6 c$ & 0 & 0 & $0.4182(3)$ & $0.9(2)$ & 1 \\
\hline
\end{tabular}

